ROJAS, Luis Emilio. "Deconstrucción del modelo dominante de comprensión de los delitos de falsedad documental".

Polít. crim. Vol. 9, № 18 (Diciembre 2014), Art. 6, pp. 477-520.

[http://www.politicacriminal.cl/Vol_09/n_18/Vol9N18A6.pdf]

\title{
Deconstrucción del modelo dominante de comprensión de los delitos de falsedad documental
}

\author{
Dr. iur. Luis Emilio Rojas A.* \\ Profesor de Derecho penal en la Universidad Alberto Hurtado \\ lurojas@uahurtado.cl
}

\section{Resumen}

La perspectiva desde la cual la doctrina y la jurisprudencia tradicionalmente leen las normas de los artículos 193, 194 y 197 del Código penal, se encuentra inmersa en una serie de dicotomías, que le impide ver el injusto propio de los delitos de falsedad documental. Estas dicotomías son cuatro: fe pública como bien jurídico colectivo / patrimonio como bien jurídico personal $\left(1^{\mathrm{a}}\right)$; documento público como portador de fe pública / documento privado como instrumento de defraudación $\left(2^{\mathrm{a}}\right)$; falsedad ideológica / falsedad material como injustos esencialmente diferentes $\left(3^{\mathrm{a}}\right)$; delito especial / delito común $\left(4^{\mathrm{a}}\right)$. El análisis de estas dicotomías y, en particular, de la tercera $\left(3^{\mathrm{a}}\right)$, permite redescubrir la distinción entre "declaraciones de ciencia" y "declaraciones de voluntad" propuesta por Francisco Grisolía en 1956 y reformular la diferenciación del concepto de verdad en el documento privado y en el documento público, propuesta recientemente por Bacigalupo en la doctrina española. Sobre la base de estas distinciones, se propone una reconstrucción dogmática del sistema de normas de los artículos 193, 194 y 197 del Código penal.

Palabras clave: Documento privado y público, autenticidad y verdad, injusto, falsedad documental.

\section{Zusammenfassung}

Der Blickwinkel, aus dem Lehre und Rechtsprechung üblicherweise die Normen der §§ 193, 194 und 197 des Strafgesetzbuchs lesen, steckt in einer Reihe von Dichotomien, die ihn hindert, das eigene Unrecht der Urkundendelikte zu fassen. Diese Dichotomien sind: öffentlicher Glaube als kollektives Rechtsgut / Vermögen als individuelles Rechtsgut (1.); öffentliche Urkunde als Träger öffentliches Glauben / Privaturkunde als Mittel zum Schaden (2.); ideelle Fälschung / materielle Fälschung als grundsätzlich unterschiedliche Unrechte (3.); Sonderdelikt / Jedermannsdelikt (4.). Die Behandlung dieser Dichotomien vor allem der dritten- ermöglicht, eine 1956 von Francisco Grisolía vorgeschlagene Unterscheidung zwischen „Wissenschaftserklärung“ und „Willenserklärung“ wieder zu entdecken und eine jüngst von Bacigalupo in der spanischen Lehre erarbeitete

\footnotetext{
* Este artículo ha sido escrito en el marco del proyecto Fondecyt N. 1110512: "Falsedades documentales: entre autenticidad y verdad. Hacia una revisión del sistema de delitos de los artículos 193 a 198 del Código penal", del cual el autor es investigador responsable; agradecimientos al asistente del Departamento de Derecho penal, Mg. Rodrigo Vergara.
} 
ROJAS, Luis Emilio. "Deconstrucción del modelo dominante de comprensión de los delitos de falsedad documental".

Differenzierung des Wahrheitsbegriffs bei der Privaturkunde und bei der öffentlichen Urkunde weiter zu entfalten. Auf der Grundlage dieser Unterscheidungen wird eine dogmatische Rekonstruktion des Normensystems der $\S \S$ 193, 194 und 197 des Strafgesetzbuchs vorgeschlagen.

Stichworte: Privaturkunde und öffentliche Urkunde, Echtheit und Wahrheit, Unrecht, Urkundenfälschung.

\section{Introducción: caso}

La forma en que la doctrina y la jurisprudencia analizan los delitos de falsedad documental responde a un modelo determinado de comprensión de los artículos 193, 194 y 197 del Código penal. Sus principales componentes se manifiestan con claridad en la solución del siguiente caso, extraído de una sentencia de la Excma. Corte Suprema, de fecha 6 de junio de 2005: el 15 de agosto de 2000, a las 00.30 horas, falleció en Arica A.O.V., a la sazón de 72 años de edad, defunción ocurrida en el Hospital de esa ciudad. El día siguiente, 16 de agosto de 2000, se presentó en una Notaría de la misma ciudad G.I.V., acompañada por un individuo, nunca identificado en el proceso, que aparentó ser A.O.V. y que, en tal calidad, procedió a suscribir con ella una escritura pública de compraventa y transferencia a G.I.V. del único inmueble del cual A.O.V. era dueño, una casa en la cual este último había convivido junto a G.I.V.. Con dicha escritura pública, G.I.V. obtuvo que el bien raíz fuera inscrito a su nombre en el Registro de Propiedades del Conservador de Bienes Raíces de Arica, con fecha 25 de agosto de 2000. Ya iniciado el proceso criminal a instancias de una hermana de A.O.V., el 3 de octubre de 2000 la Corporación Nacional de Desarrollo Indígena (CONADI) certificó que G.I.V. había "acreditado poseer la calidad de indígena perteneciente a la etnia Aymará, en conformidad con la letra b) del artículo $2^{\circ}$ de la Ley 19.253, sobre protección, fomento y desarrollo de los Indígenas”. El 12 de abril de 2001 se dictó por la CONADI una resolución que da por acreditada su calidad de cónyuge de A.O.V., a la cual se atribuye haber sido su conviviente por más de 15 años. Sobre esas bases, la imputada solicitó la posesión efectiva de los bienes del difunto, la cual se otorgó el 12 de abril de 2002, dos días después de haberse dictado sentencia condenatoria de primera instancia en su contra. ${ }^{1}$

En dicha sentencia de instancia, se condena a la imputada por el delito de estafa (art. 473 CP). Luego, la sentencia de apelación discurre sobre la base de que tales hechos configurarían más bien el delito de falsificación de instrumento público, contemplado en el art. 194, en relación con el N. 2 del art. 193 del Código penal (CP), "pero desestima esta calificación porque ese hecho punible constituye una falsedad ideológica, la cual sólo puede ser cometida por un funcionario público". Asimismo, desestima la configuración del delito de estafa del art. $473 \mathrm{CP}$, porque G.I.V. había obtenido la posesión efectiva de la herencia, a la cual pertenecía el objeto del contrato celebrado el 16 de agosto de $2000 .^{2}$ En sede de casación, la Excma. Corte Suprema anula el fallo de apelación, con la siguiente fundamentación que, en un solo considerando, resume los elementos principales que constituyen el modelo dominante de comprensión de los delitos de falsedad:

\footnotetext{
${ }^{1}$ Sentencia de la Cortes Suprema (SCS), 6 de junio de 2005, Rol N. 253-03 (considerando $3^{\circ}$ ).

${ }^{2}$ SCS, 6 de junio de 2005, Rol N. 253-03 (considerando $4^{\circ}$ ).
} 
"Que está en lo correcto la sentencia atacada cuando, siguiendo a Etcheberry, afirma que la falsedad ideológica cometida por un particular no es punible, salvo los casos más bien raros en los cuales la ley impone también a éste una obligación de decir verdad, porque en cualquier otra situación sus mentiras no afectan a la fe pública, ya que nadie está obligado a tener por verdaderas las afirmaciones que hace. Pero de lo que el fallador prescinde es de que, en la misma cita que hace del autor antes mencionado éste advierte que, 'si a través de una declaración mentirosa consignada en un documento público se crea una falsa apariencia, se engaña y se perjudica, el hecho será característicamente una estafa' (Etcheberry, Derecho Penal Parte Especial, Santiago, 1998, tomo IV, página 168). Es decir, la falsedad ideológica del particular no es punible como tal, pero si forma parte de una maquinación engañosa, dirigida a perjudicar de esa forma a los herederos del suplantado A.O.V., se integra al hecho global que, de esa manera, resulta ser subsumible en el tipo de la estafa". 3

Esta solución del caso parecería de tal obviedad a los ojos de cualquier lector de textos de doctrina nacional que no abrigaría dudas en torno a su fundamentación. Le resultaría tan natural, porque fluye de un modelo determinado de comprensión de los artículos 193, 194 y 197 del Código penal, que opera casi por inercia. Sin embargo, este modelo de comprensión se encuentra inmerso en una serie de dicotomías, que como una suerte de velo le impide a la doctrina y la jurisprudencia ver el injusto propio de los delitos de falsedad documental. Al no darse cuenta del injusto realizado, por ejemplo, en este caso, recurren a otro delito para arribar a una solución del mismo. A continuación, se pretende develar y poner en evidencia estas dicotomías, para lo cual es preciso someter este modelo a análisis en cada uno de sus componentes.

\section{Estructura del modelo imperante de comprensión de los delitos de falsedad documental: un modelo preso de una cuádruple dicotomía}

Los elementos constitutivos del modelo dominante de comprensión son básicamente cuatro (4). Cada uno de ellos conduce a una dicotomía. El primer elemento consiste en un decurso argumentativo que parte analizando la afectación de la fe pública como bien jurídico y termina discurriendo en torno a la lesión del patrimonio. Si se admite a la fe pública como un bien jurídico protegido por la norma, éste es de carácter colectivo. El patrimonio es un bien jurídico personal. Por ende, la argumentación se mueve en las antípodas de dos bienes jurídicos esencialmente distintos $\left(1^{\mathrm{a}}\right)$. El segundo elemento es reflejo del primero. A partir de la distinción entre bien jurídico u "objeto jurídico" y objeto de la acción u "objeto material", 4 la dicotomía entre fe pública y patrimonio se torna en una bifurcación del "objeto" sobre el que recae la conducta típica del delito de falsedad. Si bien se reconoce que la falsedad recae en general sobre "documentos", el documento público se erige en un auténtico portador de la fe pública. Y, tratándose de la falsedad cometida en un documento privado, conforme al tipo del art. $197 \mathrm{CP}$, ésta se cometería en perjuicio del patrimonio de otro. La consecuencia de esta perspectiva es la reducción del documento privado a un medio especial de comisión del delito de estafa (art. $468 \mathrm{CP}$ ), presentándose un concurso

\footnotetext{
${ }^{3}$ SCS, 6 de junio de 2005, Rol N. 253-03 (considerando $5^{\circ}$; destacado agregado).

${ }^{4}$ Cfr. sobre esta distinción JAKOBS, Günther, Strafrecht, Allgemeiner Teil, $2^{\mathrm{a}}$ ed., Berlin/New York: De Gruyter, 1993, Apdo. $2^{\circ}$ núm. marg. 6.
} 
ROJAS, Luis Emilio. "Deconstrucción del modelo dominante de comprensión de los delitos de falsedad documental".

aparente entre ambos delitos, que se resolvería en virtud del principio de especialidad. ${ }^{5}$ Esta argumentación se sitúa en una dicotomía entre el documento público como portador de fe púbica y el documento privado como simple medio de comisión $\left(2^{\mathrm{a}}\right)$.

Las dicotomías trabadas en el plano del bien jurídico y del objeto material condicionan la forma de comprender el injusto de las conductas descritas en los tipos de los art. 193, 194 y 197 CP. El tipo del art. 193 describe ocho (8) modalidades de comisión de la falsedad en un documento público o auténtico. Pero, como la norma subyacente a este tipo se legitima por la protección de la fe pública y el sujeto activo de este delito es un empleado público obligado a su protección, entonces la doctrina distingue entre aquellas modalidades de comisión, cuya realización presuponen la infracción de ese deber especial, y otras modalidades que no presuponen tal deber $\mathrm{y}$, por lo tanto, pueden ser realizadas por cualquier sujeto. Las modalidades de la primera clase se denominan de "falsedad ideológica" y se encuentran descritas en los numerales 2, 3 y 4 del art. 193. Las modalidades de la segunda clase se denominan de "falsedad material" y se hallan descritas en los números 1, 5 y 6 del art. 193. ${ }^{6}$ Al describir la conducta típica de la falsedad cometida en un documento público o auténtico por un particular, el texto del art. $194 \mathrm{CP}$ remite a cualquiera de las modalidades de comisión descritas en el art. 193 precedente. Sin embargo, la doctrina sostiene que las modalidades de "falsedad ideológica", aun cuando recaigan en un documento público, solamente pueden ser realizadas por un particular puniblemente, en la medida en que éste se encuentre obligado especialmente a la protección de la fe pública. ${ }^{7}$ Tratándose de la falsedad cometida en un instrumento privado, descrita en el tipo del art. $197 \mathrm{CP}$, no obstante que su texto remite también a cualquiera de las falsedades designadas en el art. 193, la doctrina sostiene que, por el carácter patrimonial de este delito, el sujeto activo solamente puede realizar puniblemente las modalidades de comisión de "falsedad material". ${ }^{8}$ De esta manera, una distinción que tiene su origen en una mera clasificación de modalidades de comisión de la falsedad se transforma en una diferenciación cualitativa de injustos $\left(3^{\mathrm{a}}\right)$.

El cuarto componente es reflejo de los anteriores en la dimensión de los sujetos. Ya que la norma del art. $193 \mathrm{CP}$ protege a la fe pública como bien jurídico colectivo, resultaría coherente que se castigue al empleado público que comete falsedad en un documento público. Puesto que el empleado público se encuentra especialmente obligado a la

\footnotetext{
${ }^{5}$ ETCHEBERRY, Alfredo, Derecho penal, parte especial, t. IV, $3^{\text {a }}$ ed., Santiago: Editorial Jurídica de Chile, 1997, p. 177; POLITOFF, Sergio; MATUS, Jean Pierre; RAMÍREZ, María Cecilia, Lecciones de Derecho Penal Chileno, parte especial, reimpresión de la $2^{\mathrm{a}}$ edición, Santiago: Editorial Jurídica de Chile, 2009, pp. 451, 567-568.

${ }^{6}$ ETCHEBERRY, Derecho penal, cit. nota $n^{\circ}$ 5, pp. 161 y ss.; GARRIDO, Mario, Derecho penal, parte especial, t. IV, $4^{\text {a }}$ ed., Santiago: Editorial Jurídica de Chile, 2008, pp. 63 y ss.; POLITOFF/MATUS/RAMÍREZ, Lecciones de Derecho penal, cit. nota ${ }^{\circ}$ 5, pp. 562-563; VARGAS, Tatiana, La falsificación de instrumento privado, Un estudio práctico entre la falsificación y la estafa, Santiago: Thomson Reuters, 2013, pp. 60 y ss.

${ }^{7}$ ETCHEBERRY, Derecho penal, cit. nota ${ }^{\circ}$ 5, p. 168; GARRIDO, Derecho penal, cit. nota ${ }^{\circ}$ 6, p. 63, 82; POLITOFF/MATUS/RAMÍREZ, Lecciones de Derecho penal, cit. notas n 5, pp. 563-564; recientemente, HERNÁNDEZ, Héctor, en: HERNÁNDEZ, Hector; COUSO, Jaime (dirs.), Código penal comentado, Santiago: Thomson Reuters, 2011, comentario al art. 15, p. 393.

${ }^{8}$ ETCHEBERRY, Derecho penal, cit. nota n ${ }^{\circ}$ 6, p. 173 y s., 176; GARRIDO, Derecho penal, cit. nota n ${ }^{\circ}$ 6, p. 87 y s.
} 
protección de la fe pública. Para los efectos de las reglas de autoría y participación, se trataría de un delito especial propio. ${ }^{9}$ En cambio, la norma del art. 194, que expresamente castiga al particular que comete alguna falsedad en documento público, sería contradictoria. Porque el particular, en principio, no se encuentra obligado especialmente a la protección de la fe pública. Por su parte, la falsificación de documento privado, según el tipo del art. 197 CP que no exige ninguna calidad especial respecto del sujeto activo, es un delito común para los efectos de la autoría y la participación. En esta sede de análisis, la argumentación se mueve en las antípodas del empleado público como sujeto especial del delito de falsedad en documento público y del particular como sujeto innominado del delito de falsificación en documento privado, alcanzando su paroxismo en la interpretación del art. 194, en contra de su texto expreso, como un delito especial $\left(4^{\mathrm{a}}\right)$.

\subsection{Primera dicotomía: bien jurídico colectivo / bien jurídico personal - entre correcta administración pública y patrimonio}

El origen de la tesis de la fe pública para la justificación del castigo de la falsedad documental no se remonta al Derecho romano. ${ }^{10} \mathrm{Su}$ origen es más bien moderno y se encuentra indisolublemente ligado al nombre de Gaetano Filangieri: "Los delitos contra la fe pública forman un apéndice de los delitos contra el orden público. Servirse un ciudadano de la confianza pública que en él se ha depositado para faltar á las obligaciones que de la misma dependen, es el carácter de los delitos comprehendidos en esta clase", entre los cuales incluye el peculado en los administradores y depositarios de las rentas públicas, "el delito de falsedad en los notarios ó receptores públicos", la falsificación o alteración de la moneda entre las personas encargadas del cuño público, revelar los secretos del estado la persona pública que es depositaria. ${ }^{11}$ Posteriormente, Francesco Carrara subraya el carácter colectivo ínsito a la fe pública, al sostener que la no falsificación de documentos públicos "interesa a todos los ciudadanos; así, con esa falsedad, se ofende un derecho universal y el delito encuentra su objeto jurídico en la fe pública, la cual exige el respeto a las solemnidades impuestas, con miras de orden público, para comprobar las convenciones y disposiciones de los ciudadanos". ${ }^{12}$ En estos pasajes ya clásicos, es posible notar dos ideas que van a perdurar, con distintas formulaciones de la doctrina, a lo largo de todo el siglo XX. La primera es la asociación de la fe pública a la noción de orden público, que determina el carácter eminentemente colectivo del interés jurídicamente protegido. La segunda es la agrupación bajo este mismo acápite y, por ende, la asociación del delito de falsificación de monedas con el de falsedad en documentos públicos. Ambas asociaciones fueron consagradas legislativamente en la sistemática del Code Pénal de $1810 .{ }^{13} \mathrm{El}$

\footnotetext{
${ }^{9}$ En la doctrina española, GARCÍA CANTIZANO, María del Carmen, Falsedades documentales (en el Código penal español de 1995), Valencia: Tirant lo Blanch, 1997, p. 133.

${ }^{10}$ Cfr. D’ORS, Alvaro, "Contribución a la historia del 'crimen falsi"”, en: VOLTERRA, Edoardo (Ed.), Studi in onore di Edoardo Volterra, vol. II, Milano: Giuffrè, 1969, p. 546; recientemente, BOLDOVA PASAMAR, Miguel Angel, Estudio del bien jurídico protegido en las falsedades documentales, Granada: Editorial Comares, 2000, pp. 35 y ss.

${ }^{11}$ FILANGIERI, Gaetano, Ciencia de la legislación, Madrid: Imprenta de Nuñez,1813, p. 151 y s.

12 CARRARA, Francesco, Programa de Derecho criminal, PE vol. VII, $5^{\mathrm{a}}$ ed., Santa Fe de Bogotá: Temis, 1996, § 3660 (destacado original).

${ }^{13}$ Cfr. ROJAS, Luis Emilio, "Historia dogmática de la falsedad documental", Revista de Derecho de la Pontificia Universidad Católica de Valparaíso (2ºm. 2012), pp. 556 y ss.
} 
ROJAS, Luis Emilio. "Deconstrucción del modelo dominante de comprensión de los delitos de falsedad documental".

legislador nacional también las acogió en el Título IV “De los crímenes y simples delitos contra la fe pública, de las falsificaciones, del falso testimonio y del perjurio" del Libro II del Código penal, dejando expresa constancia de esa decisión en las sesiones 42 en 5 de junio de 1871 y 170 en 8 de octubre de $1873 .{ }^{14}$ Estas dos asociaciones alcanzan una formulación sintética en el siguiente concepto acuñado por Manuel Rivacoba:

"es posible definir la fe pública como la confianza generalizada en la autenticidad y el valor de ciertos objetos, signos o documentos que suscita o impone la garantía que les despensa el Estado, sea directamente o a través de las instituciones o los funcionarios o ministros en quienes delega al efecto". 15

La tesis de la fe pública ha sufrido fuertes críticas. Ya Karl Binding la calificaba de "insalubre". ${ }^{16}$ Entendida en la acepción de Filangieri, vale decir, en el sentido de una "posición personal de confianza" que resulta abusada, pierde relación con la falsedad como tal. ${ }^{17} \mathrm{Si}$ se reformula en los términos de un abuso, no de una posición personal de confianza, sino que de objetos autentificados públicamente o de signos o medios auténticos públicos, se produce una escisión en los delitos de falsedad, pues la que se comete en documentos privados debe consecuentemente excluirse de este grupo de delitos. ${ }^{18}$ En el caso de la falsedad cometida en objetos, en los cuales se tiene fe en su verdad por ley o costumbre y que, por ende, constituyen las bases de la confianza pública, se trata de objetos en cuya credibilidad la colectividad tendría un derecho correlativo a un deber general de no lesionarla. Binding advierte que en esta formulación aparece nuevamente el antiguo derecho a la verdad, solamente que restringido a ciertas relaciones y objetos. ${ }^{19}$ Respecto de la versión de Ortloff de esta tesis, ${ }^{20}$ según la cual este delito no puede radicar en la alteración de la verdad, sino que en la lesión del derecho general a la fe pública mediante alteración u ocultación de formas específicas de autenticidad, observa que este derecho a la credibilidad del objeto se torna disimuladamente en una pretensión del objeto a ser creído. Sin embargo, la fe pública del documento público, su fuerza probatoria de la verdad de su contenido, surge solamente de la persona de su otorgante: ¿cómo se podría asignar al documento privado una pretensión similar? ${ }^{21}$

\footnotetext{
${ }^{14}$ Actas de las sesiones de la Comisión Redactora del Código penal chileno, Santiago: imprenta de la República de Jacinto Nuñez, 1873 (edición facsímil, Santiago 2013): en Sesión 42, "manifestó el señor Renjifo que, a su juicio, no debía formarse un título aparte de la falsificación de documentos, según estaba acordado, sino considerar esta materia como parte del título IV que trata de los delitos contra la fé pública, dividiéndolo en dos párrafos distintos, uno relativo a los instrumentos públicos auténticos i partes telegráficos, i el otro a los documentos privados, etc. Así se acordó"; en Sesión 170: "A indicación de Gandarillas se modificó el epígrafe del título IV, diciéndose: 'De los crímenes i simples delitos contra la fé pública, de la falsificacion, del falso testimonio i del perjurio', porque de todas estas materias se trata en él”.

${ }^{15}$ RIVACOBA Y RIVACOBA, Manuel, "Objeto jurídico y sujeto pasivo de la falsificación de monedas", Gaceta Jurídica $\mathrm{N}^{\circ} 70$ (1996), p. 4 (destacado original).

${ }^{16}$ BINDING, Karl, Lehrbuch des gemeinen deutschen Strafrechts, BT vol. II, Leipzig: W. Engelmann, 1904, p. 120.

${ }^{17}$ BINDING, Lehrbuch, cit. nota ${ }^{\circ} 16$, p. 121.

${ }^{18}$ BINDING, Lehrbuch, cit. nota n ${ }^{\circ} 16$, p. 121 y s.

${ }^{19}$ BINDING, Lehrbuch, cit. nota ${ }^{\circ} 16$, p. 124.

${ }^{20}$ Cfr. ROJAS, "Historia dogmática", cit. nota n 13 , p. 575 y s.

${ }^{21}$ BINDING, Lehrbuch, cit. nota n ${ }^{\circ} 16$, p. 125 y s.
} 


\section{Polít. crim. Vol. 9, № 18 (Diciembre 2014), Art. 6, pp. 477-520. [http://www.politicacriminal.cl/Vol_09/n_18/Vol9N18A6.pdf]}

En la doctrina nacional, ya a mediados del siglo XX la tesis de la fe pública es sometida a una crítica acérrima. Según Luis Cousiño, "parece de toda evidencia que existe una confianza pública (...) en los instrumentos otorgados por un Notario. Pero creemos que ella no es un bien jurídico que tenga ninguna relevancia para el derecho". ${ }^{22}$ Suscribe esta crítica Alfredo Etcheberry cuando constata que, "desde luego, esta confianza general existe, pero se trata de un simple hecho social"; ${ }^{23}$ en cuanto tal, no puede mandarse ni imponerse a los ciudadanos. De ahí que Etcheberry identifique como bien jurídico, en lugar de la confianza general, los efectos jurídicos de obligatoriedad general que la ley asigna a los objetos materiales indicados en el título IV, entre los cuales se incluye la moneda, ciertos valores mobiliarios y los documentos públicos. ${ }^{24}$ Para determinar cuáles objetos se encuentran dotados de estos efectos atribuidos por la ley, la autoridad se vale de signos o símbolos materiales autentificados. Se trata entonces de la protección de la eficacia de estos símbolos materiales autentificados, esto es, que los efectos jurídicos atribuidos por la ley a estos objetos, efectivamente se produzcan, puesto que de este modo se posibilita que el tráfico jurídico funcione. ${ }^{25}$

Esta mirada puesta en los efectos que despliegan estos signos materiales en el tráfico jurídico, va a ser desarrollada ulteriormente por la doctrina española de fines del siglo XX, bajo el influjo de la teoría del bien jurídico. Específicamente respecto del documento, dicha doctrina recurre a la teoría de las funciones, desarrollada en el ámbito de la dogmática alemana, para determinar el bien jurídico protegido por la norma del art. 390 del Código penal español de $1995 .{ }^{26}$ En este sentido, María del Carmen García Cantizano destaca la triple función que cumple el documento, cual es, la función de garantía, la de perpetuación y la de medio de prueba. Sostiene que el bien jurídico protegido es "la propia funcionalidad del documento en las diversas misiones que tiene que cumplir en el tráfico jurídico". ${ }^{27}$ Esta triple función se vería amagada en cualquier delito de falsedad, sea que se cometa en un documento público o mercantil o en un documento privado (art. 392, 395 Código penal

\footnotetext{
${ }^{22}$ COUSIÑO, Luis, "La falsificación de instrumento privado", Revista de Ciencias Penales, $2^{\mathrm{a}}$ época, t. VII (1944), p. 11 (destacado agregado); crítico también COUTURE, Eduardo Juan, Estudios de Derecho procesal civil, t. II, $3^{\text {a }}$ ed., Buenos Aires: Ed. De Palma, 1998, pp. 27 y ss.

${ }^{23}$ ETCHEBERRY, Alfredo, "El objeto jurídico en los delitos de falsedad documental", Revista de Ciencias

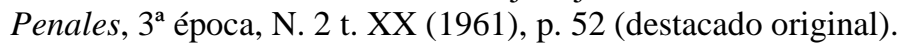

${ }^{24}$ ETCHEBERRY, "El objeto jurídico", cit. nota n ${ }^{\circ} 23$, pp. 57 y ss.

${ }^{25}$ ETCHEBERRY, "El objeto jurídico", cit. nota n 23, p. 60 y s.

26 “Art. 390. 1. Será castigado con las penas de prisión de tres a seis años, multa de seis veinticuatro meses e inhabilitación especial por tiempo de dos a seis años, la autoridad o funcionario público que, en el ejercicio de sus funciones, cometa falsedad: $1^{\circ}$ Alterando un documento en alguno de sus elementos o requisitos de carácter esencial; $2^{\circ}$ Simulando un documento en todo o en parte, de manera que induzca a error sobre su autenticidad; $3^{\circ}$ Suponiendo en un acto la intervención de personas que no la han tenido, o atribuyendo a las que han intervenido en él declaraciones o manifestaciones diferentes de las que hubieran hecho; $4^{\circ}$ Faltando a la verdad en la narración de los hechos".

${ }^{27}$ GARCÍA CANTIZANO, Falsedades documentales, cit. nota $\mathrm{n}^{\circ}$ 9, pp. 40-43, autora que habla de "medio de prueba" y no de "función probatoria", probablemente por la crítica que dirige a la tesis de Binding de incurrir en un "reduccionismo procesal" (pp. 37 y ss.); BOLDOVA PASAMAR, Estudio del bien jurídico protegido, cit. nota $\mathrm{n}^{\circ} 10$, pp. 153 y ss., somete la teoría de las funciones a un análisis crítico, principalmente a la función de perpetuación, por no contemplar el Código penal español un tipo de supresión u ocultación documental (p. 160 y s.), pero concluye que queda a salvo la protección de las funciones de garantía y probatoria: "pero ello no es sino la protección de la autenticidad y veracidad en las formas de manifestación documental que son relevantes para el tráfico jurídico" (p. 165).
} 
ROJAS, Luis Emilio. "Deconstrucción del modelo dominante de comprensión de los delitos de falsedad documental".

español). ${ }^{28}$ Sin embargo, Carolina Villacampa Estiarte observa que, tratándose de la falsedad cometida por un funcionario público en ejercicio de sus funciones (art. $390 \mathrm{CP}$ español), además de afectarse el objeto común a todo delito de falsedad documental, se atenta contra el buen funcionamiento de la Administración como prestadora de servicios a los ciudadanos, "o a la misma función pública, puesto que el encargado público documentador en una específica situación realiza su cometido de forma desviada, desfigurando así la imagen de corrección con la que la Administración ha de aparecer frente a quienes sirve". ${ }^{29}$ Como puede observarse, a pesar de todo el desarrollo dogmático que ha significado la teoría de las funciones, la doctrina reciente no ha logrado despegarse totalmente de la tesis de la fe pública, en la versión acuñada por Filangieri a fines del siglo XVIII.

Esta asociación entre fe pública y correcto desempeño de la función pública, empero, se restringe a la hipótesis de falsedad cometida por un funcionario público en un documento público. En el polo opuesto se ubica la hipótesis de falsedad cometida por un particular en un documento privado. Ya Carrara oponía la fe pública que deriva de la autenticidad de la cual está dotado el documento público, por la intervención del funcionario público, a la fe privada que cada persona puede o no otorgar a la verdad de la declaración emitida por un particular. ${ }^{30}$ Dada la índole social de este delito, para configurar la falsedad en documento público basta con un daño potencial. En cambio, para la configuración de la falsedad en un documento privado, se requiere provocar un daño efectivo, por eso Carrara incluye esta forma de falsedad en "la familia de los fraudes". ${ }^{31}$ En este mismo sentido y dado que el tipo del art. 197 CP exige para su realización "perjuicio de tercero", la doctrina nacional concibe el delito de falsedad realizada en un documento privado como un "atentado contra la propiedad". 32 Sin embargo, la propiedad es un bien jurídico personal, esto es, correlativo a

\footnotetext{
${ }^{28}$ Suscribe la teoría de las funciones también VILLACAMPA ESTIARTE, Carolina, La falsedad documental: análisis jurídico penal, Barcelona: Cedecs, 1999, pp. 102 ss., pp. 445 y ss., donde esta autora asocia la función de perpetuación a la modalidad del art. 390 N. 1 (p. 445 y s.), la función de garantía a la del art. 390 N. 2 (pp. 447 y ss.), la modalidad del art. 390 N. 3 tendría una naturaleza híbrida (p. 526 y s.) y la función probatoria subyacería a la modalidad del art. 390 N. 4 CP 1995 (p. 547).

${ }^{29}$ VILLACAMPA ESTIARTE, La falsedad documental, cit. nota $\mathrm{n}^{\circ} 28$, p. 96 (destacado agregado); en sentido similar, GARCÍA CANTIZANO, Falsedades documentales, cit. nota $\mathrm{n}^{\circ}$ 9, p. 110: "la falsa declaración realizada por el funcionario, si bien integra un supuesto de falsedad documental, vería superado el contenido de la antijuridicidad material de este delito por el específico significado que tiene, en tales casos, la condición de funcionario en cuanto autor del ilícito".

${ }^{30}$ CARRARA, Programa de Derecho criminal, cit. nota ${ }^{\circ} 12, \S 3659$.

${ }^{31}$ CARRARA, Programa de Derecho criminal, cit. nota ${ }^{\circ} 12, \S 3680$.

32 ETCHEBERRY, "El objeto jurídico", cit. nota $\mathrm{n}^{\circ} 23$, p. 63; en el mismo sentido, POLITOFF/MATUS/RAMÍREZ, Lecciones de Derecho penal, cit. nota $\mathrm{n}^{\circ} 5$, p. 451, quienes al entenderlo como una forma de estafa, comprenden que es un delito que afecta el patrimonio e incluso lo analizan someramente a propósito de las figuras de estafa; en la jurisprudencia, ya SCS, "Caja Nacional de Ahorros Contra Carlos Alberto Balbontín”, casación en el fondo, resolución de 30/09/1947, en Gaceta de los Tribunales, Año 1947, $2^{\circ}$ semestre, sentencia 45, pp. 244 y ss. (considerandos $2^{\circ}$ y $3^{\circ}$ ), señalando que la falsificación de instrumentos privados mercantiles es un delito contra la propiedad y de la misma especie que el delito de estafa; SCS, "Contra Luis Alberto Montt Olate”, casación en el fondo, resolución de 28/09/1955, en Revista de Derecho y Jurisprudencia y Gaceta de los Tribunales, año 1955, p. 186, exigiendo perjuicio patrimonial efectivo (considerandos $2^{\circ}, 5^{\circ}$ y $6^{\circ}$ ); SCS, "Contra Sergio Raúl Veas Veas", resolución de 4/05/1959, en RDJGT, año 1959, t. LVI, mayo y junio de 1959, $\mathrm{N}^{\circ} 3$ y 4, pp. 80 y ss. (considerandos $5^{\circ}$ y $6^{\circ}$ ), que comprende que en los hechos investigados el perjuicio patrimonial se produjo a la víctima en el caso de
} 


\section{Polít. crim. Vol. 9, № 18 (Diciembre 2014), Art. 6, pp. 477-520. [http://www.politicacriminal.cl/Vol_09/n_18/Vol9N18A6.pdf]}

un derecho individual. De este modo, la doctrina se coloca en una dicotomía. Se ve obligada a explicar racionalmente cómo un mismo sistema de normas, que fue concebido originariamente de modo unitario a partir del concepto de fe pública, se torna, por decirlo expresivamente así, bicéfalo. Con una norma, la subyacente al tipo del art. $193 \mathrm{CP}$, cuyo fin es la protección también del correcto funcionamiento de la administración pública, esto es, de un bien jurídico cuyo titular es la colectividad toda. Y otra norma, la del art. $197 \mathrm{CP}$, cuyo fin es la protección del patrimonio, es decir, de un bien jurídico personal, del cual es titular una persona. Sistemáticamente, la primera norma del sistema se vincularía más bien con los delitos funcionarios contra la administración pública, mientras que la última pertenecería más bien al grupo de los delitos patrimoniales (art. 467 y ss. CP). Esta perspectiva sistemática produce una escisión conceptual al interior de este sistema de normas, con masivas consecuencias en la aplicación práctica del modelo (vid. infra 3.).

\subsection{Segunda dicotomía: documento público / documento privado - una diferencia esencial}

La vinculación de la norma del art. 193 CP con la noción de fe pública y, por este intermedio, con un bien jurídico de carácter eminentemente colectivo, así como la agrupación de este delito junto a otros que atacan también objetos dotados de "efectos de obligatoriedad general" -monedas, sellos del Estado, etc.-, trae como consecuencia una escisión en el concepto de documento. Esta cesura se produce mediante un doble movimiento conceptual: primero, mediante la ampliación del concepto de documento público al documento oficial $\mathrm{y}$, segundo, mediante la diferenciación del concepto de

un cheque falsificado al haber entregado el girador un cheque "sin valor"; recientemente, SCS, Rol N. 35571999, "Contra Sepúlveda Fuica", casación en el fondo, resolución de 16/11/1999, comprendiendo que el perjuicio en la falsificación de instrumento privado es de carácter económico (considerando $1^{\circ}$ de la sentencia de reemplazo), pero sin entrar a calificar a dicha figura como forma especial de estafa; SCS, Rol N. 34812009, señala que el bien jurídico protegido en el delito del art. 197 del Código Penal es la propiedad (considerandos $3^{\circ} \mathrm{y}^{\circ}$ ); una interpretación de carácter excepcional, dentro de la postura del máximo tribunal, en SCS, "Contra Francisco Segundo Marín Almonacid y otros", casación en el fondo, resolución de 11/08/1970, RDJGT, t. LXVII, pp. 318 y ss. (considerando $7^{\circ}$ ), al señalar que en las falsificaciones de instrumentos mercantiles se ataca principalmente a la fe pública y no sólo el patrimonio privado; SCS, "Contra Castillo Cabrera", casación en el fondo, resolución de 3/07/1963, RDJGT, año 1963, t. LX, julio y agosto de 1963 , $\mathrm{N}^{\circ} 5$ y 6 , pp. 326 y ss. (considerando $15^{\circ}$ ), haciendo presente que la diferencia sustancial entre la falsificación de instrumento privado mercantil y la estafa, se da a nivel de bienes jurídicos protegidos por dichas figuras, expresando que la estafa mira a la protección de intereses patrimoniales mientras que la falsificación en comento mira a la protección de la fe pública, no obstante compartir ambas figuras un elemento común, constituido por la defraudación patrimonial con perjuicio de tercero; en contra de una concepción patrimonial de la falsedad documental, COUSIÑO, "La falsificación", cit. nota $n^{\circ} 22$, p. 13, el bien jurídico protegido es "siempre el mismo", la fe probatoria (p. 19, p. 109 y s.); ORTIZ, Pedro, "La falsificación de instrumento privado", Revista de Ciencias Penales (1944), p. 208 y s., también en la falsificación de documento privado se vulnera la fe pública; RODRÍGUEZ COLLAO, Luis; VERA, Jaime, "El bien jurídico protegido en los delitos de falsedad", Revista de Derecho de la Universidad Católica de Тетисо, año 5 núm. 5 (2004), parecen seguir una tesis pluriofensiva, pero recurriendo al difuso concepto de "bien jurídico espiritualizado o intermedio", constituido, "en nuestra postura, por el interés concreto de la seguridad del tráfico que se tome como referencia según el delito de que se trate (funcionalidad documental, sistema de pagos, etc.), el cual siempre resultaría lesionado o puesto en concreto peligro, sea que se trate de una falsedad de uso o de una mera falsificación y, por su parte, existiría, además, un bien inmaterial: la seguridad en el tráfico, entendida como concepto amplio que englobaría al bien intermedio y que sería siempre puesta en peligro de manera abstracta a través de los comportamientos falsarios, cualquiera sea la modalidad de que se trate" (p. 132). 
ROJAS, Luis Emilio. "Deconstrucción del modelo dominante de comprensión de los delitos de falsedad documental".

documento mercantil del de documento privado. La identificación de los "efectos de obligatoriedad general" como denominador común a un grupo de objetos dotados de "signos materiales autentificados" conduce tendencialmente a la inclusión del documento oficial en el concepto de documento público. Puesto que la intervención del empleado público en el otorgamiento del documento se vuelve constitutiva de éste como documento público. En este sentido, Etcheberry destaca que, aunque se trate de un documento originalmente privado, otorgado por particulares, éste adquiere el carácter de público por la intervención del funcionario que, al participar en su generación o "tomarlo bajo su custodia" por mandato legal, lo dota de un "efecto de general obligatoriedad", por ejemplo, un documento privado protocolizado en una Notaría. ${ }^{33}$ Lo relevante, entonces, sería la intervención del funcionario público, pues ésta dota al documento de tales efectos. Este criterio conduce naturalmente a la aceptación del documento oficial como público para los efectos del tipo del art. 193 CP. Ya que el documento oficial se encuentra precisamente despojado de la intervención de particulares, los cuales pueden haber participado en la fase previa mediante la entrega de antecedentes, pero no en la generación misma del documento, en ésta interviene solamente el funcionario público. ${ }^{34}$ El documento oficial se convierte así por esencia en el prototipo del documento público. En este sentido, en la doctrina española, Fernández propone dos criterios para admitir el documento oficial como público. Primero, la expedición del mismo por parte de un ente de carácter oficial y, segundo, que su contenido, "mediante la potencial o efectiva intervención en el tráfico jurídico, venga constituido por una disposición o declaración que afecte servicios o funciones de carácter público". 35

En la vereda opuesta, el documento privado se define por la ausencia de intervención del empleado público. Así, Etcheberry lo define por exclusión como "el que, respondiendo en general a las características propias del documento, no constituya un documento público". 36 Estos atributos definitorios del documento serían básicamente tres (3): primero, que tenga un autor, una persona humana; segundo, que tenga un valor simbólico, en el sentido de representar algo: "un hecho o una manifestación de voluntad"; y, tercero, que "su simbolismo se haya independizado de su autor en una materialidad". ${ }^{37}$ Sin embargo, estos elementos constitutivos del documento, por sí mismos, carecen de relevancia, como tales no son dignos de protección jurídico-penal. De ahí que su falsificación constituye, según esta tesis, un mero peligro que no alcanza el umbral de relevancia jurídico-penal consagrado en el tipo del art. 197 CP. Relevancia jurídico-penal en el sentido de este tipo alcanzaría la falsificación de documento privado solamente en la medida en que provoque un "perjuicio que pueda ser avaluado pecuniariamente", por lo que resultaría claro que ésta es "solamente un delito contra la propiedad caracterizado por su especial manera de

\footnotetext{
${ }^{33}$ ETCHEBERRY, "El objeto material del delito de falsedad documental", Revista de Ciencias Penales, $3^{\mathrm{a}}$ época, N. 2, t. XX (1961), p. 236.

${ }^{34}$ Cfr. ETCHEBERRY, "El objeto material”, cit. nota ${ }^{\circ} 33$, pp. 234 y ss.

${ }^{35}$ FERNÁNDEZ, Pilar, Delito de falsedad en documento público, oficial y mercantil, Madrid: Marcial Pons, 1996, p. 162.

${ }^{36}$ ETCHEBERRY, "El objeto material”, cit. nota $\mathrm{n}^{\circ}$ 33, p. 237 (destacado agregado).

${ }^{37}$ ETCHEBERRY, "El objeto material", cit. nota $n^{\circ} 33$, p. 227: puede definirse el documento como "todo objeto que representa un hecho o una manifestación de pensamiento, emanado de un autor y fijado en forma permanente" (in fine).
} 


\section{Polít. crim. Vol. 9, № 18 (Diciembre 2014), Art. 6, pp. 477-520. [http://www.politicacriminal.cl/Vol_09/n_18/Vol9N18A6.pdf]}

comisión". 38 Si se exige un perjuicio pecuniario, entonces se trataría de una defraudación patrimonial cometida mediante un documento privado falso, es decir, una forma especial de estafa caracterizada por el medio de comisión. ${ }^{39}$ Esta concepción de la falsedad en documento privado como delito patrimonial implica que la sola falsificación del mismo e incluso su circulación, configuran un injusto irrelevante. El injusto de este delito se realizaría recién cuando se provoca un perjuicio patrimonial a otro. Esta tesis explicativa del injusto de este delito tiene su reflejo a nivel del objeto material sobre el que recae la conducta típica de falsificación. La consecuencia en este nivel de análisis es la irrelevancia del documento como tal, éste no es portador de un interés jurídico por sí mismo digno de protección. Relevancia jurídico-penal alcanzaría este delito solamente cuando el documento privado falsificado es utilizado como instrumento de la defraudación patrimonial. Si el documento como tal y sus elementos constitutivos se vuelven irrelevantes, entonces su análisis también se torna fútil. La consecuencia metodológica de esta tesis es que el análisis del concepto de documento se relega a un plano completamente secundario, lo cual explica la menguada dedicación que la doctrina y la jurisprudencia le conceden a esta institución básica de la parte especial del Derecho penal. ${ }^{40}$

${ }^{38}$ ETCHEBERRY, "El objeto jurídico", cit. nota n 23, p. 63 .
${ }^{39}$ ETCHEBERRY, Derecho penal, cit. nota n ${ }^{\circ} 5$, p. 177; GARRIDO, Derecho penal, cit. nota n 6 , p. 93 y s.; POLITOFF/MATUS/RAMÍREZ, Lecciones de Derecho penal, cit. nota $\mathrm{n}^{\circ}$ 5, pp. 451, 562-563; en la jurisprudencia, la fórmula que se ha impuesto entiende que hay un concurso aparente de leyes entre falsificación de instrumento privado y estafa, que se resuelve por principio de especialidad, así SCS, "Contra Luis Urquieta Núñez", recurso de casación en el fondo, resolución de 4/08/1952, RDJGT, t. XLIX, Julio y Agosto de 1952, $\mathrm{N}^{\circ} 5$ y 6, $2^{\mathrm{a}}$ parte, sección $4^{\mathrm{a}}$, pp. 217 y ss. (considerandos $6^{\circ}$ a $8^{\circ}$ ); SCS, "Contra Eduardo Alberto Barraza Jorquera”, recurso de casación en el fondo, resolución de 7/11/1958, RDJGT, Año 1958, t. LV, noviembre y diciembre de $1958, \mathrm{~N}^{\circ} 9$ y 10 , pp. 184 y ss. (considerandos $9^{\circ}$ a $12^{\circ}$ del voto de mayoría); nuevamente y sin explicitarlo, soluciona por vía del concurso aparente por especialidad en favor de la falsificación de instrumento privado mercantil por sobre la estafa, SCS, "Contra Hoffen Minio", resolución de 27/04/1964, RDJGT, año 1964, t. LXI, enero a abril de 1964, N 1 y 2, pp. 86 y ss. (considerando $6^{\circ}$ ); SCS, "Contra Francisco Segundo Marín Almonacid y otros", casación en el fondo, resolución 11/08/1970, RDJGT, t. LXVII, $2^{a}$ parte, pp. 318 y ss. (considerandos $5^{\circ}$ y $6^{\circ}$ ); SCS, “Contra José Hernán García Massry”, casación en el fondo, resolución de 26/01/1972, RDJGT, t. LXIX, año 1972, Enero-Abril, N¹-2, pp. 11 y ss. (considerandos $3^{\circ}$ a $5^{\circ}$ ); SCS, “Contra Luis Álvarez Figueroa y otro", casación en la forma y en el fondo, resolución de 23/06/1976, RDJGT, t. LXXIII, año 1976, enero - diciembre de 1976, pp. 174-180, donde se hace referencia expresa a la especialidad del medio comisivo (considerando $8^{\circ}$ ); más recientemente, SCA Stgo, Rol N. 1122-2007, resolución de 14/11/2008, aplica el mismo criterio del concurso aparente, solucionado por principio de especialidad (considerando $1^{\circ}$ ); SCA Stgo, Rol N. 2413-2009, resolución de 12/11/2009, señala que entre los delitos de estafa y de falsedad de instrumento privado, existe concurso aparente, que se resuelve aplicando tanto el principio de especialidad como el de consunción, por lo que la falsificación documental queda subsumida en el engaño propio de toda estafa (considerando $2^{\circ}$ ).

${ }^{40}$ Cuatro (4) páginas en ETCHEBERRY, Derecho penal, cit. nota n ${ }^{\circ} 5$, pp. 154-157; cinco (5) páginas en GARRIDO, Derecho penal, cit. nota ${ }^{\circ}$ 6, pp. 53-57; POLITOFF/MATUS/RAMÍREZ, Lecciones de Derecho penal, cit. nota $\mathrm{n}^{\circ} 5$, pp. 556, 567-568 y 570; la jurisprudencia a su turno, realiza un enfoque de descarte, considerando que al no existir un concepto legal de documento privado, será entendido como tal todo aquel que no pueda ser estimado como instrumento público, teniendo presente que respecto a este último concepto hay definición legal expresa en el Código Civil, así, por ejemplo, SCA Stgo, "contra Santander Letelier", apelación, resolución de 14/05/1985, RDJGT, t. LXXXII, año 1985, pp. 155-159 (considerando $4^{\circ}$ ); sin perjuicio de ello, se destaca excepcionalmente SCA Stgo, "Contra Nolberto Olguín Olguín”, por falsificación de instrumento privado, casación en la forma y apelación subsidiaria, resolución de 10/11/1955, RDJGT, t. LIII, año 1956, septiembre y octubre, $\mathrm{N}^{\circ} 7$ y 8, pp. 113 y ss., que se explaya derechamente sobre un concepto general del delito en comento y sobre las características que debe tener el documento privado en cuanto a su contenido para efectos de su incriminación al tenor del artículo 197 y cómo dicho contenido se conecta con la 
ROJAS, Luis Emilio. "Deconstrucción del modelo dominante de comprensión de los delitos de falsedad documental".

En cambio, el documento mercantil y su falsificación reciben una atención diferente. En este sentido, Etcheberry reconoce que doctrinariamente tal clase de documentos tiene una relevancia jurídica que trasciende la repercusión patrimonial privada, pues los documentos mercantiles tienen un valor económico representado por su expendibilidad y aptitud circulatoria, "que puede resultar lesionado [nótese: el valor del documento] aun antes de que se haya producido un efectivo daño patrimonial por el fracaso de su finalidad cancelatoria". Por ejemplo, una letra de cambio que tiene valor no por el aceptante sino por la solvencia del avalista, cuya firma es falsificada, el documento está "comercialmente muerto" aun cuando no se haya producido un efectivo perjuicio patrimonial mientras no se proteste la letra e incluso cuando el aceptante la pague a su vencimiento. ${ }^{41}$ Mediante su falsificación se afectaría no solamente al patrimonio, sino al tráfico comercial, "a toda la vasta serie de relaciones económico-jurídicas que se fundamentan en la confianza en la autenticidad de los documentos". ${ }^{42}$ La repercusión de la falsificación de un documento mercantil, a diferencia de la cometida en documento privado, trascendería entonces la esfera patrimonial y vulneraría intereses colectivos del comercio y de la economía. En este sentido, el legislador español incluso equipara la falsificación del documento mercantil cometida por un particular con la realizada en un documento público u oficial en el art. 392 N. 1 del Código penal de 1995. Este no fue el criterio seguido por el legislador nacional de 1874, pues esta clase de falsificación aparece regulada en el art. 197 inciso $2^{\circ} \mathrm{CP}$ sobre falsedad cometida en documento privado, aunque con una pena mayor que la asignada a esta última. En consecuencia, se parte de la premisa que el documento mercantil de lege lata es un documento privado, lo cual a su vez no es óbice a que Etcheberry proponga una interpretación restrictiva del concepto de documento mercantil: el legislador se refiere aquí a documentos que expresamente la ley comercial califica de tales, como la letra de cambio, "títulos-valores" o "documentos negociables", que se caracterizan por su transferibilidad y aptitud circulatoria, pero "no a cualquier documento que dé testimonio de una operación comercial", por ejemplo, no una escritura privada de compraventa mercantil. ${ }^{43}$

En este sentido, en la doctrina española también se buscan y proponen criterios que expliquen la equiparación valorativa entre falsedad en documento público u oficial y falsificación de documento mercantil introducida por la norma del art. 392 N. 1 del CP español de 1995. Así, Villacampa Estiarte propone como criterio de "equivalencia material" la característica de ejecutoriedad de que gozan algunos documentos mercantiles. El valor ejecutivo de documentos regulados en leyes mercantiles, pero reconocido por la Ley de Enjuiciamiento Civil (art. 1429 LEC), es considerado como un criterio de dicha equiparación valorativa para efectos penales. ${ }^{44}$ Otro criterio refiere a aquellos documentos emitidos en cumplimiento de obligaciones específicas de determinados sujetos en el ámbito mercantil, por ejemplo, en las actas confeccionadas de juntas de accionistas, en la medida en que gozan de fe para ese concreto cometido y los secretarios funcionan como una

exigencia del perjuicio a terceros; el criterio aludido repercute adicionalmente al estimar que, a falta de un documento como el mencionado, únicamente es posible considerar el documento falsificado como un medio engañoso de la estafa, mas no como un caso de falsificación de instrumento privado (considerando $3^{\circ}$ a $5^{\circ}$ ).

${ }^{41}$ ETCHEBERRY, "El objeto jurídico", cit. nota n² 23, p. 64.

${ }^{42}$ ETCHEBERRY, "El objeto jurídico", cit. nota n 23, p. 64.

${ }^{43}$ ETCHEBERRY, "El objeto material", cit. nota n ${ }^{\circ} 33$, p. 238.

${ }^{44}$ VILLACAMPA ESTIARTE, La falsedad documental, cit. nota n ${ }^{\circ} 28$, pp. 276 y ss. 


\section{Polít. crim. Vol. 9, № 18 (Diciembre 2014), Art. 6, pp. 477-520. \\ [http://www.politicacriminal.cl/Vol_09/n_18/Vol9N18A6.pdf]}

"suerte de fedatarios privados normativamente cualificados". ${ }^{45}$ De este modo, sería posible distinguir documentos mercantiles dotados de "una mayor eficacia jurídica", ya sea por el valor ejecutivo asignado legalmente o porque surgen del cumplimiento de obligaciones específicas "que funcionalmente los acerque a los documentos emitidos por ciertos funcionarios públicos documentadores", cuya falsificación, en consecuencia, tendría un mayor contenido de injusto en comparación a la de otros documentos que, en fin, habrían de considerarse meramente privados, como por ejemplo, contratos mercantiles, facturas, recibos, libros. ${ }^{46}$

De este modo, la doctrina busca un criterio externo al documento mismo para poder diferenciar el contenido de injusto de la falsificación. Este criterio externo al documento lo encuentra la doctrina en la distinta clase de efectos que éste produce o en la diferente eficacia jurídica de la cual está dotado. Este criterio, sin embargo, es equívoco, pues no queda claro si los efectos o la eficacia jurídica a la cual se refiere, radican en los efectos del acto jurídico fijado en el documento o en la eficacia propia de éste y distinta del acto jurídico. La expresión "efectos de obligatoriedad general" lleva a pensar que se contraponen a "efectos de obligatoriedad particular". Pero, así comprendido el criterio, implicaría que la escritura pública de compraventa de un bien raíz no sería un documento público, puesto que de ésta nacen derechos y obligaciones solamente para las partes. Más bien dichos efectos aluden a una eficacia jurídica propia del documento y distinta del acto jurídico fijado en éste, de la cual el documento se encuentra dotado por la intervención de un funcionario público. Pero, entonces, la escritura privada de compraventa de un vehículo motorizado, cuyas firmas son autorizadas ante un Notario conforme al art. $401 \mathrm{~N} .10$ del COT, de acuerdo a dicho criterio así comprendido, debería considerarse un documento público para efectos penales. Esta consecuencia puede evitarse en la medida en que se aclara que no basta cualquier intervención del empleado público, ésta debe realizarse en virtud de un mandato legal y, además, de cierta forma, alternativamente, participando en la generación misma del documento o tomándolo "bajo custodia", forma esta segunda que concurre tratándose de un documento privado protocolizado en una Notaría, pero no en la hipótesis del mismo cuyas firmas solamente son autorizadas por esta última.

De esta manera se relevan los dos criterios que deben concurrir para aceptar un documento oficial como público, cuales son, que emane de un ente de carácter oficial y que contenga una disposición o declaración que afecte el servicio o la función pública. Estos dos criterios coinciden con los elementos característicos de un documento administrativo, ${ }^{47}$ según la definición del art. 3, inciso $1^{\circ}$ e inciso $2^{\circ}$, de la Ley 19.880, sobre procedimientos administrativos. $^{48}$ Estos elementos característicos, a su turno, entregan los criterios para que

\footnotetext{
${ }^{45}$ VILLACAMPA ESTIARTE, La falsedad documental, cit. nota ${ }^{\circ} 28$, p. 282 y s.

${ }^{46}$ VILLACAMPA ESTIARTE, La falsedad documental, cit. nota $\mathrm{n}^{\circ}$ 28, p. 285.

${ }^{47}$ Cfr. sobre el punto en la doctrina española, MARTÍNEZ-PEREDA, José Manuel, "Las falsedades en documentos oficiales", en: VV. AA., Las falsedades documentales, Libro homenaje a Enrique Ruiz Vadillo, Granada: Comares, 1994, pp. 91 y ss., p. 95 y s., p. 100: "Documento oficial es equivalente a documento administrativo, en sentido amplio, contraponiéndose a los notariales y judiciales, también con amplitud en cuanto comprensivos a los certificados del Registro civil"; sin embargo: "El Código penal no hace iguales documentos públicos y documentos oficiales, ni tampoco hace de éstos una especie de aquéllos" (p. 100).

48 Art. $3^{\circ}$ Ley 19.880: "Las decisiones escritas que adopte la Administración se expresarán por medio de actos administrativos. Para efectos de esta ley se entenderá por acto administrativo las decisiones formales que
} 
ROJAS, Luis Emilio. "Deconstrucción del modelo dominante de comprensión de los delitos de falsedad documental".

la doctrina diferencie entre clases de documentos mercantiles, aquellos equivalentes materialmente al documento público u oficial y aquellos que son meramente documentos privados. Así, a partir del elemento característico que el documento emane de un ente oficial por mandato legal se extrae el criterio de las específicas obligaciones establecidas legalmente a las que se encuentran afectos ciertos particulares y que los constituyen en una suerte de fedatarios con una función similar que "acerca" a los documentos que de ellos emanan a los documentos públicos u oficiales. Por otro lado, a partir del elemento característico de la relevancia de la disposición o declaración contenida en el documento para el servicio o la función pública se extrae el criterio de la "mayor eficacia jurídica" para diferenciar cierta clase de documentos mercantiles. De este modo, se propone el criterio de la ejecutoriedad o valor ejecutivo del documento, en nuestro ordenamiento jurídico establecido en el art. 434 CPC, con arreglo al cual, por ejemplo, una letra de cambio o un título de crédito al portador o nominativo, serían documentos mercantiles, no así el documento en el cual se vierte una compraventa mercantil o un mandato comercial (art. $3^{\circ}$, N. $1^{\circ}$ y N. $4^{\circ}$ del Código de Comercio), que, entonces, sería un mero documento privado. Pero, si uno se fija bien, la diferencia entre uno y otro documento mercantil radica en que, en el primer ejemplo, además de los efectos jurídicos consistentes en los derechos y obligaciones que surgen del acto jurídico, existe otro efecto jurídico consistente en la inmediata ejecutoriedad del título, lo que permite hablar de una "mayor eficacia jurídica".

Sin embargo, que un documento tenga menor eficacia jurídica, porque, por ejemplo, contiene una compraventa mercantil de la cual surgen solamente derechos y obligaciones para las partes, no significa que no tenga ninguna eficacia jurídica. Detrás de este razonamiento parece esconderse inconscientemente la decimonónica cláusula de relevancia jurídica introducida en 1851 por el legislador prusiano al párrafo $2^{\circ}$ del $\S 247$ del Código penal, que buscaba distinguir documentos de meros escritos. ${ }^{49}$ La relevancia jurídica de un

emitan los órganos de la Administración del Estado en las cuales se contienen declaraciones de voluntad, realizadas en el ejercicio de una potestad pública".

${ }^{49} \S 247$ párrafo $2^{\circ}$ Preußisches StGB: "Se entiende por documento todo escrito de relevancia para la prueba de contratos, disposiciones, obligaciones, liberaciones o en general de derechos o relaciones jurídicas"; cfr. al respecto ROJAS, "Historia dogmática", cit. nota $\mathrm{n}^{\circ}$ 13, p. 579 y s.; muy crítico de esta cláusula de relevancia jurídica KIENAPFEL, Urkunden im Strafrecht, Frankfurt a.M. 1967, pp. 306 y ss.; EL MISMO, „Urkundenbegriff und ,Rechtserheblichkeit““, Zeitschrift für die gesamte Strafrechtswissenschaft, vol. 82 (1970), pp. 345 y ss., en tanto se la comprende como un atributo externo que se agrega al documento: "un predicado determinado, un atributo derechamente misterioso" (p. 345), "si se revisa esta 'relevancia jurídica' más de cerca, ésta se escapa rápidamente a la esfera sublime de la abstracción, construcción sintética y conceptualización esotérica" (p. 347); "se requiere sin embargo de un análisis muy profundo del laberinto jurisprudencial de fórmulas para darse cuenta que la 'relevancia jurídica' ha perdido toda autonomía y justificación existencial como elemento del concepto jurídico-penal de documento" (p. 366); la "relevancia jurídica" del documento para el tráfico jurídico radica en la "corporeización de una declaración escrita que deja reconocer a su otorgante. Esta es al mismo tiempo su definición completa” (p. 366 y s.); la declaración y la reconocibilidad del otorgante son los elementos constitutivos del documento mismo, al cual la "determinación o aptitud para la prueba de un hecho" no le agrega nada (p. 374 y s.); "pues todos los criterios que constituyen actualmente el concepto de documento han sido deducidos y desarrollados desde el antiguo reservorio conceptual y de fórmulas de la 'relevancia jurídica'. La pregunta por la 'relevancia jurídica' del documento jurídico-penal es, por ende, idéntica con la pregunta por su tipicidad" (p. 376; destacado agregado); Kienapfel critica en esos pasajes el proceso de asimilación y agotamiento conceptual que ha sufrido dicha cláusula en la doctrina y, especialmente, en la jurisprudencia, transformándose en una suerte de "válvula político-criminal" para resolver los casos dudosos y límites de falsedad documental; sin embargo, en 
documento puede ser menor o mayor, por ende, se trata de un criterio gradual y cuantitativo. No obstante, la doctrina aplica este criterio de tal manera que le permite diferenciar, por un lado, documentos públicos, oficiales o mercantiles que, por la clase de efectos que producen, son considerados auténticos portadores de fe pública o privada equivalente a ésta y que, por lo tanto, su falsificación alcanza un injusto per se de relevancia jurídico-penal por la afectación de intereses colectivos. Y, por otro lado, meros documentos privados del cual surgen efectos jurídicos solamente particulares, por estar dotados de una fe puramente privada y que, por ende, su falsificación tiene un contenido de injusto deficitario que requiere ser compensado con la verificación de la lesión a un bien jurídico personal, como es el patrimonio, para alcanzar relevancia jurídico-penal.

De este modo, la doctrina presa de este modelo de comprensión aplica la relevancia jurídica como un criterio esencial y cualitativo que diferencia entre, por un lado, documentos propiamente tales -documentos públicos, oficiales y mercantiles equivalentes a éstos-, que per se son dignos de protección e inmediatamente relevantes jurídicamente. Y, por otro lado, documentos deficitarios -documentos privados y mercantiles equivalentes a éstos-, que per se son indignos de protección y cuya relevancia jurídica es mediata por estar supeditada a la lesión de un bien jurídico personal. Se trata de una cesura conceptual que es reflejo de la primera dicotomía a nivel de bienes jurídicos protegidos (supra 2.1.) y que parece ser consecuencia del olvido en el cual ha caído el concepto de documento. ${ }^{50}$

\subsection{Tercera dicotomía: falsedad ideológica / falsedad material - transformación de una simple clasificación de modalidades de comisión en una diferenciación esencial de injustos}

La distinción entre falsedad ideológica y falsedad material tiene su origen en una clasificación de modalidades de comisión del crimen de falsedad, propuesta y desarrollada por la doctrina francesa y la Cour de Casation en el siglo XIX, para explicar sistemáticamente las normas de los artículos 145 y siguientes del Code Pénal de $1810 .{ }^{51}$ En ese contexto, la distinción tenía un sentido acotado, solamente servía para diferenciar modalidades de comisión del crimen de falsedad. La respuesta a la pregunta por la configuración de este delito dependía, según dicha doctrina y jurisprudencia, de la concurrencia del elemento material y del elemento moral, extraídos del concepto de crimen falsi desarrollado por la doctrina italiana medieval tardía. De ahí que, por ejemplo, frente a

\footnotetext{
la evolución de la legislación penal alemana, ha sufrido un proceso de "migración normativa" desde su lugar derechamente errado como concepto en el inciso $2^{\circ}$ del $\S 247$ del Preuß. StGB, a su reubicación también errada como elemento típico delimitador del documento privado en el $§ 267$ del Reichsstrafgesetzbuch -cuya función es la misma que la asignada por el legislador nacional al elemento "perjuicio a tercero" en el art. 197 inciso $1^{\circ} \mathrm{CP}$ - hasta llegar a su ubicación correcta como elemento típico delimitador del hecho "jurídicamente relevante" que consta en el documento público objeto de la falsificación mediata tipificada en el $§ 271$ o de la falsedad en el cargo del § 348 StGB.

${ }^{50}$ Sobre este concepto y la trascendencia dogmática de su rescate del olvido en el cual ha caído en la tradición jurídica iberoamericana ROJAS, Luis Emilio, "Falsedad documental como delito de engaño", Revista Chilena de Derecho, Pontificia Universidad Católica de Chile, 2014 (en prensa), importancia consistente en que, metodológicamente, antes de determinar el carácter público o privado, oficial o mercantil, debe responderse a la pregunta de si se está en presencia de un documento.

${ }^{51}$ Cfr. ROJAS, "Historia dogmática de la falsedad documental", RDPUCV, 2012 vol. $392^{\circ}$ sem., pp. 556 y ss.; VILLACAMPA ESTIARTE, La falsedad documental, cit. nota $\mathrm{n}^{\circ} 28$, pp. 327 y ss.; GARCÍA CANTIZANO, Falsedades documentales, cit. nota n 9, p. 108 (nota 63).
} 
ROJAS, Luis Emilio. "Deconstrucción del modelo dominante de comprensión de los delitos de falsedad documental".

la pregunta por la punibilidad de la falsedad intelectual cometida por un particular en un documento público, René Garraud hallaba el contenido de injusto no simplemente en la declaración mentirosa del particular, porque tampoco ésta fundamenta meramente el injusto cuando es emitida por el funcionario público. Tampoco se castiga al funcionario público simplemente por emitir una declaración mentirosa. El criterio para resolver dicha pregunta radicaba en la circunstancia que esa declaración falsa se vertía en un escrito, esto es, la creación o desnaturalización, por medio de esa declaración falsa, de un escrito destinado a servir de prueba, es lo que fundamenta la punibilidad también del particular. ${ }^{52}$

A mediados del siglo XX, en la doctrina española Antonio Quintano Ripollés propuso relacionar la clasificación entre falsedad ideológica y falsedad material con la distinción, propuesta por un comercialista (Aparicio Ramos), entre falsedad y falsificación, respectivamente. Así, en la falsedad hay una simple imitación (poner lo falso en el lugar que debiera ocupar lo verdadero) y en la falsificación una sustitución (esto es, poner lo falso en el lugar antes ocupado por lo auténtico). ${ }^{53}$ A renglón seguido, precisa esa distinción reservando la palabra genérica falsedad "para las actividades criminales que no supongan una realización material de sustitución, alteración o creación" y la más específica falsificación "para estas últimas", vale decir, realización material de sustitución, alteración o creación, distinción que se aproxima a la traducción de la palabra alemana "Fälschung" como forma ideal de falsedad y "Verfälschung" como formas materiales. ${ }^{54}$ No obstante, Quintano aclaró que la cuestión aludida es de "puro lujo léxico", ya que en el Código penal español a la sazón vigente, así como en la praxis de la época, dichas palabras resultaban sinónimas. ${ }^{55}$ Esta aclaración no era óbice para clasificar los numerales del art. 302 del Código penal español de mediados del siglo $\mathrm{XX}$, cuyo texto en los números 1 a 7 era idéntico a los mismos numerales del art. $193 \mathrm{CP}$, en "falsificación física" y "falsedad ideológica". De este modo, Quintano Ripollés relaciona los numerales 1 ("contrahaciendo o fingiendo letra, firma o rúbrica"), 5 ("alterar las fechas verdaderas") y 6 ("haciendo en documento verdadero cualquiera alteración o intercalación que varíe su sentido"), con la "falsificación física" o "falsedad material", en que considera vulnerada lo que llamaba la "genuinidad" del documento, aludiendo a la autenticidad del mismo. Mientras que los numerales 2 ("suponiendo en un acto la intervención de personas que no la han tenido"), 3 ("atribuyendo a las que han intervenido en él declaraciones o manifestaciones diferentes de las que hubieren hecho") y 4 ("faltando a la verdad en la narración de los hechos"), contemplan modalidades de "falsedad ideológica" que Quintano Ripollés vincula con lo que llamaba "veracidad" del documento, aludiendo a la verdad del mismo. ${ }^{56}$ En cuanto al numeral 7 ("dando copia en forma fehaciente de un documento supuesto o manifestando en ella cosa contraria o diferente de la que contenga el verdadero"), lo denominaba una hipótesis de "falsedad de transcripción" y el numeral 8 ("intercalando cualquier escritura en un protocolo, registro o libro oficial"), lo consideraba una modalidad "idéntica a la falsedad material del núm. 6" sólo que realizada en un documento de "carácter plural y total

\footnotetext{
${ }^{52}$ GARRAUD, René, Droit Pénal Français, $2^{\mathrm{a}}$ ed., Larose, Paris 1899, t. III, p. 527 nota 37.

${ }^{53}$ QUINTANO RIPOLLÉS, Antonio, La falsedad documental, Reus, Madrid 1952, p. 26.

${ }^{54}$ QUINTANO RIPOLLÉS, La falsedad documental, cit. nota ${ }^{\circ}$ 53, p. 26.

${ }^{55}$ QUINTANO RIPOLLÉS, La falsedad documental, cit. nota ${ }^{\circ}$ 53, p. 26.

${ }^{56}$ QUINTANO RIPOLLÉS, La falsedad documental, cit. nota n ${ }^{\circ} 53$, pp. $176-184$.
} 
(“Gesamturkunden" en la terminología germánica)". ${ }^{57}$ Por último, respecto del número 9 ("simulando un documento de manera que induzca a error sobre su autenticidad"), introducido por el legislador español en 1944 al art. 302 del Código penal, lo calificaba de redundante al comprender "la falsificación, por decirlo así, total del documento que es elaborado de la nada y que, por lo tanto, ha de repetir hipótesis ya previstas en los números anteriores, pues no se concibe la falsificación total de un todo sin la de sus partes, como firmas, letras, fingida presencia de personas o alteración de la verdad de los hechos".58

Sin embargo, en la recepción que la doctrina nacional hace de esta distinción, se le asigna a ésta un significado que trasciende al de una mera clasificación de modalidades de comisión. Así, Etcheberry distingue $1^{\mathrm{o}}$ "la imitación de un modelo verdadero, y la alteración de un objeto auténtico" y $2^{\circ}$ "la mendacidad de lo manifestado en un documento que formalmente es auténtico. A la primera forma se llama falsedad material; a la segunda, falsedad ideológica". ${ }^{59} \mathrm{Al}$ agrupar los numerales 1 a 7 del art. 193 entre modalidades de falsedad ideológica y de falsedad material, este autor sigue la misma clasificación propuesta por Quintano Ripollés. ${ }^{60}$ Por su parte, Garrido relaciona esta distinción con una diferenciación en sede de autoría y participación:

"La ideológica, por ejemplo, puede llevarla a cabo únicamente un sujeto cualificado, un funcionario público, porque es un delito especial; en tanto que la falsedad material puede ser cometida por cualquiera persona, funcionario o no, ya que se trata de un delito común, al igual que la falsificación por $u s o "{ }^{\prime 61}$

Como puede observarse en este pasaje, se relaciona una distinción de modalidades de realización de la conducta típica del delito de falsedad, cuestión que depende básicamente de la forma de interpretar el tipo, con una clasificación entre delitos especiales y delitos comunes, que habitualmente la doctrina tematiza recién en sede de autoría y participación para resolver hipótesis de pluralidad de intervinientes en la realización del mismo delito. Este salto en el análisis desde una cuestión de parte especial a un problema de parte general del Derecho penal en materia de falsedades documentales es también frecuente detectarlo en la doctrina española más moderna. ${ }^{62}$

¿Por qué se realiza este salto metodológico? Porque en sede de autoría y participación se vuelve relevante la pregunta por los deberes especiales a los cuales puede estar sujeto uno

${ }^{57}$ QUINTANO RIPOLLÉS, La falsedad documental, cit. nota $\mathrm{n}^{\circ}$ 53, pp. 185 - 187; sobre esta clase de documento en la doctrina nacional crítico GUZMÁN DALBORA, José Luis, Estudios y defensas penales, $3^{\mathrm{a}}$ ed., Santiago 2009, p. 514 y s.

${ }^{58}$ QUINTANO RIPOLLÉS, La falsedad documental, cit. nota $\mathrm{n}^{\circ}$ 53, p. 187 (destacado agregado).

${ }^{59}$ ETCHEBERRY, Derecho penal, cit. nota ${ }^{\circ} 5$, p. 161 (destacado original).

${ }^{60}$ ETCHEBERRY, Derecho penal, cit. nota ${ }^{\circ} 5$, , pp. 162-164, casos de falsedad ideológica: números 2,3 y 4 del art. 193, número 7 es de "falsedad transcriptiva"; casos de falsedad material: números 1, 5 y 6, la modalidad del número 8 es de "falsedad por ocultación”, pp. 165-167; sigue esta clasificación recientemente VARGAS, Falsificación de instrumento privado, cit. nota $\mathrm{n}^{\circ} 6$, pp. 60 y ss.

${ }^{61}$ GARRIDO, Derecho penal, cit. nota ${ }^{\circ} 6$, p. 63.

${ }^{6}$ GARCÍA CANTIZANO, Falsedades documentales, cit. nota $\mathrm{n}^{\circ}$ 9, pp. 109 y ss.; VILLACAMPA ESTIARTE, La falsedad documental, cit. nota $\mathrm{n}^{\circ}$ 28, pp. 526 y ss., 547 y ss.; BACIGALUPO, Enrique, Falsedad documental, estafa y administración desleal, Madrid/Barcelona/Buenos Aires: Marcial Pons, 2007, pp. $25 \mathrm{y}$ ss. 
ROJAS, Luis Emilio. "Deconstrucción del modelo dominante de comprensión de los delitos de falsedad documental".

de los intervinientes en el mismo hecho y, en consecuencia, la cuestión de si el título de imputación puede o no ser el mismo. En esta sede de análisis, los delitos especiales se diferencian de los delitos comunes, porque el autor se encuentra sujeto a un status determinado, cuya concurrencia es presupuesto de aplicación de la norma, y que se asocia a un plexo de deberes. ${ }^{63}$ Pero, salvo que se proponga una reformulación teórica de esta distinción, ${ }^{64}$ la doctrina le asigna la acotada relevancia de servir para la explicación diferenciada del fundamento de la autoría y no para la justificación racional del injusto del delito. Sin embargo, en este ámbito específico de la parte especial del Derecho penal, la doctrina extrae de esta distinción entre delitos especiales y delitos comunes un criterio que resulta determinante respecto del injusto de los delitos de falsedad documental. Así, Etcheberry, al analizar la norma del art. 194 que alude al particular que comete en documento público alguna de las falsedades designadas en el art. $193 \mathrm{CP}$, advierte que "parecería que la tipicidad de la falsificación de documento público es la misma cuando el sujeto activo es un empleado público que cuando es un particular". A continuación, observa que esta asimilación es correcta, cuando se trata de casos de falsedad material, pero que no lo es en relación a los casos de falsedad ideológica. En palabras del propio Etcheberry, que por su influencia, evidenciada en el fallo de la Excma. Corte Suprema arriba citado (supra 1.), se reproducen textualmente:

"Ellos consisten, en general, en mentir en un documento. Y si la ley los pena tratándose de empleados públicos, ello se debe a que únicamente éstos están obligados por la ley a decir la verdad, porque solamente sus declaraciones van a ser prueba de lo consignado. Ello no ocurre con los particulares que concurren a la formación de un documento público. No están jurídicamente obligados a decir la verdad y, por consiguiente, el documento no tiene un valor de general obligatoriedad en cuanto a la veracidad del fondo de las declaraciones que formularon. No se puede ver, por consiguiente, en la eventual mentira en que incurren, la violación de ningún bien jurídico, ni un atentado contra la fe pública, en ninguna forma que se la considere, ni un quebrantamiento de deber jurídico alguno. Ahora, si a través de una declaración mentirosa consignada en un documento público se crea una falsa apariencia, se engaña y se perjudica, el hecho será característicamente una estafa, pero no una falsedad en documento público. La falsedad ideológica es propia y personalísima del funcionario que interviene en la formación, autorización o emisión del documento público, ya que sólo en su caso puede la mentira lesionar la fe pública, el valor probatorio o la seguridad del tráfico jurídico". 65

\footnotetext{
${ }^{63}$ Cfr. sobre la categoría de los delitos de infracción de deber ROXIN, Claus, Täterschaft und Tatherrschaft, $8^{a}$ ed., Berlin: de Gruyter Recht, 2006, § 34, pp. 352 ss.: "Para esta [categoría] es característico que el portador de estos deberes se destaca de los otros intervinientes por una relación especial con respecto al contenido de injusto del hecho y que por eso el legislador la releva solamente en aras de este deber como la figura central del acontecimiento conforme a la acción y lo ve como autor" (p. 354).

${ }^{64}$ Así, JAKOBS, Strafrecht, cit. nota n ${ }^{\circ} 4$, Apdo. 7 núm. marg. 70 y s., reformula la categoría de los delitos de infracción deber para la explicación del fundamento de la responsabilidad: "en estos delitos, la responsabilidad del autor se determina por el status, no según el ámbito de organización del autor".

${ }^{65}$ ETCHEBERRY, Derecho penal, cit. nota ${ }^{\circ}$ 5, p. 168; en el mismo sentido, GARRIDO, Derecho penal, cit. nota $\mathrm{n}^{\circ}$ 6, p. 82; POLITOFF/MATUS/RAMÍREZ, Lecciones de Derecho penal, cit. nota $\mathrm{n}^{\circ}$ 5, pp. 563564.
} 
Aquí se observa cómo el recurso al status especial del funcionario público sirve para explicar el injusto de determinadas modalidades de comisión del delito de falsedad documental que la doctrina agrupa bajo el acápite de la falsedad ideológica. Mientras que en los casos de falsedad material el injusto del delito es el mismo y, en esa medida, la asimilación de la tipicidad de la conducta, esto es, la descripción típica común al art. 193 y al art. $194 \mathrm{CP}$, es correcta, por lo que el status especial del funcionario público sólo sirve para explicar la diferencia en la penalidad de ambas figuras, ocurriría algo diferente tratándose de casos de falsedad ideológica. En estos casos, la asimilación de la tipicidad de la conducta sería incorrecta, porque la mentira en un escrito, esto es, la declaración falsa plasmada en un documento público configuraría un injusto en la medida en que se infringen los deberes de decir verdad impuestos por la ley solamente a los empleados públicos. En cambio, la misma conducta típica, esto es, la declaración falsa vertida en un documento público, realizada por un particular, no configuraría el injusto de este delito, pues la ley no impone a los particulares el deber de decir verdad.

Pero, ¿qué ley es aquella que impone a los empleados públicos tal deber y no a los particulares? No puede tratarse de la propia ley penal ni del art. 193 ni del art. 194 CP, sin caer irremediablemente en un argumento circular: la asimilación de la tipicidad de la conducta establecida en el artículo 193 y en el artículo 194 CP es incorrecta, porque la ley penal del art. 193 establece el deber de decir verdad, cuya infracción configura el injusto del delito, y la ley penal del art. 194 no establece un deber de decir verdad, cuya infracción pueda constituir el injusto del delito. Debe tratarse, entonces, necesariamente de una ley pre-penal, civil o administrativa, cuya existencia sea presupuesto de aplicación de la ley penal del art. 193 al empleado público y cuya inexistencia impida la aplicación de la ley penal del art. 194 al particular, no obstante haberse realizado la misma conducta típica. ¿De cuál ley pre-penal puede tratarse? En la argumentación sometida a análisis es posible observar que el deber especial del empleado público a decir la verdad, que resulta determinante para la pregunta por la configuración del injusto de este delito, se colige del valor probatorio de la declaración emitida por el funcionario en el documento público. Dado que solamente la declaración emitida por este empleado tiene valor probatorio, entonces solamente su mentira, su declaración falsa vertida en este documento podría configurar el injusto del delito. En cambio, como la declaración emitida por el particular carece de valor probatorio, entonces su mentira, la declaración falsa del particular vertida en el documento público no podría constituir el injusto del mismo delito. Pero, frente a la pregunta, ¿en qué se basa el valor probatorio de la declaración emitida por el funcionario público, del cual no se encuentra dotada la declaración emitida por el particular?, la argumentación se torna nuevamente circular: el valor probatorio de la declaración emitida por el funcionario público surge del deber que éste tiene a decir la verdad y la ausencia de tal valor en la declaración emitida por el particular es consecuencia de que éste no tiene deber de decir la verdad. La irremediable circularidad de la argumentación deriva precisamente del intento de colegir tal deber del valor probatorio de la declaración vertida en el documento público.

Podría aún evitarse la circularidad de la argumentación en la medida en que se razonara, ya no normativamente, sino que, por decirlo así, descriptivamente: el valor probatorio de la declaración emitida por el funcionario público no surge de ningún deber especial de éste y 
ROJAS, Luis Emilio. “Deconstrucción del modelo dominante de comprensión de los delitos de falsedad documental".

ningún deber puede colegirse del valor probatorio de dicha declaración. El valor probatorio de la declaración emitida por el empleado público surgiría de la circunstancia fáctica de que aquélla ha sido emitida por un funcionario. En cambio, de la declaración emitida por un particular no surgiría ningún valor probatorio. Esta forma de argumentar implicaría derivar un atributo de la declaración, su valor probatorio, de la circunstancia de haber sido emitida por un sujeto determinado: la fuerza probatoria de la declaración reposa en la autoridad del sujeto que la emite. Esta argumentación aplicaría como criterio diferenciador del valor probatorio de la declaración la calidad del sujeto que la emite. Sin embargo, este criterio subjetivo no ha sido recogido por la ley pre-penal originaria y constitutiva del sistema probatorio en el ordenamiento jurídico nacional, el artículo 1700 del Código civil:

"El instrumento público hace plena fe en cuanto al hecho de haberse otorgado y su fecha, pero no en cuanto a la verdad de las declaraciones que en él hayan hecho los interesados. En esta parte no hace plena fe sino contra los declarantes.

Las obligaciones y descargos contenidos en él hacen plena prueba respecto de los otorgantes y de las personas a quienes se transfieran dichas obligaciones y descargos por título universal o singular.".

\subsubsection{La propuesta de reformulación teórica de Francisco Grisolía}

Este regla fundamental del Código civil diferencia el valor probatorio del documento, no según si la declaración ha sido emitida por el funcionario o por las partes que concurren ante él. Esta regla básica diferencia el valor probatorio del documento público, primero, según la clase de declaración de que se trata y, segundo, según aquello sobre el cual ésta recae. En este sentido, Grisolía, en una nota a una sentencia de la Ilma. Corte de Apelaciones de Concepción de fecha $1^{\circ}$ de diciembre de 1954, distingue, siguiendo al procesalista Eduardo Couture, ${ }^{66}$ entre declaraciones de ciencia (o de verdad) y declaraciones de voluntad: "en las primeras su autor reproduce, limitándose a ella, una percepción sensible; representa lo que percibe por sus sentidos. En las declaraciones de voluntad se manifiesta un querer". ${ }^{67}$ Ya esta diferenciación de clases de declaraciones resulta iluminadora, pues vincula la cuestión de la verdad con las declaraciones de ciencia y no con las declaraciones de voluntad. Resulta lógica, porque solamente respecto de las declaraciones de ciencia puede emitirse un juicio de verdad o de falsedad, según si la representación por medio de los sentidos se encuentra en correspondencia o no con lo percibido. En cambio, respecto de las declaraciones de voluntad no puede emitirse un juicio de verdad o de falsedad, simplemente porque no expresan una representación que pueda corresponderse o no con algo externamente percibido. Respecto de esta clase de declaraciones, solamente puede constatarse si se ha manifestado o no se ha manifestado una voluntad. $^{68}$

\footnotetext{
${ }^{66}$ COUTURE, Estudios de Derecho procesal civil, cit. nota n ${ }^{\circ}$ 22, pp. 34 y ss., p. 57: "Documento representativo de ciencia o de simple saber es aquel en el cual se reproduce una percepción (...) Documento representativo de voluntad, es aquel en el cual el autor consigna su querer".

${ }^{67}$ GRISOLÍA, "Nota", Revista de Ciencias Penales, 3 a época N. 2 (1956), t. XV, p. 95.

${ }^{68}$ Cfr. PUPPE, Ingeborg, ,Nomos Kommentar”, en: KINDHÄUSER, Urs; NEUMANN, Ulfrid; PAEFFGEN, Hans-Ullrich (Eds.), §§ 267, 271, 348 StGB, 4a ed., Baden-Baden: Nomos Verlag, 2013, 4ª ed., 2013, § 271 número marginal 13, 348 núm. marg. 5; PUPPE, Ingeborg, „Die Wahrheitspflicht des Notars“, en:
} 
A continuación, Grisolía, en una interpretación sistemática del art. 1700 con el art. 17 del Código civil, distingue grados de eficacia probatoria de estas declaraciones. En esta escala gradual se encuentran, en primer lugar, las declaraciones de ciencia hechas por un funcionario público en la órbita de sus funciones, que incluyen las que representan hechos propios y suyos $\left(1^{\circ}\right)$, las que expresan datos sensibles percibidos por sus propios sentidos $\left(2^{\circ}\right)$ y las que representan hechos que ha podido comprobar por los medios que expresamente le suministra la ley $\left(3^{\circ}\right)$. Estas declaraciones de ciencia gozan de plena eficacia probatoria, la cual reposa en una "certeza jurídica de verdad" y que, correlativamente, impone un deber de veracidad a su autor. Luego, Grisolía reconoce a las demás declaraciones de ciencia y las declaraciones de voluntad un cierto grado "(con matices progresivos)" de eficacia probatoria, la que reposa ya no en una certeza jurídica de verdad, sino que en una presunción de sinceridad o de verdad, que como tal admite su desconocimiento por simple prueba en contrario. ${ }^{69}$ Esta interpretación sería coherente con el bien jurídico protegido por la norma, el cual radicaría en "el valor probatorio del documento, su integridad y pureza que dependen no sólo de su existencia jurídica como tal y de su genuinidad, sino también de su veracidad en los extremos en que la ley ofrece la certeza de su verdad (...)".70 Este análisis permite delimitar con mayor precisión las modalidades de falsedad ideológica descritas en los números 2, 3, 4 y 7 del art. 193, que, entonces, tendrían como característica común la mentira en las declaraciones de ciencia que implica un desconocimiento del deber de veracidad. De este modo, Grisolía responde a la pregunta por el sujeto que puede cometer la modalidad de falsedad ideológica del art. 193 N. 4 CP, consultando "a quien incumbe como norma el deber de veracidad". 71 No cabe duda que este deber pesa como norma general sobre el funcionario público respecto de sus declaraciones de ciencia destinadas a dar plena fe, no así sobre el particular, en quien "no gravita un deber de tal naturaleza puesto que sus declaraciones (de ciencia o de voluntad) no revisten tan grave trascendencia probatoria". ${ }^{72}$ De donde colige que solamente el funcionario público podría cometer dicha modalidad de falsedad ideológica en relación con sus declaraciones de ciencia de plena eficacia probatoria, ya que esta veracidad en cuanto valor incorporado al contenido del documento integra el complejo de valores que forman el bien jurídico tutelado por la norma. Mientras que el particular no podría realizar puniblemente esta modalidad en relación con sus declaraciones de ciencia o de voluntad, puesto que éstas gozan de un mera presunción de verdad o sinceridad, lo cual se seguiría, además, del reconocimiento de la simulación en el art. 1707 CC sobre contraescrituras lícitas. Esta regla general que rige respecto del particular encontraría una excepción cuando la ley le asigna el mismo valor probatorio a su declaración e impone, correlativamente, un deber de ser verídico, como ocurriría en ejemplos de legislación comparada - art. 483 del CP italiano y art. 293 del CP argentino. ${ }^{73}$

KINDHÄUSER, Urs, Strafrechtliche Aspekte notarieller Tätigkeit, Baden-Baden: Normos Verlag, 2009, pp. 9 y ss.

${ }^{69}$ GRISOLÍA, "Nota", cit. nota n ${ }^{\circ} 67$, p. 96.

${ }^{70}$ GRISOLÍA, "Nota", cit. nota n ${ }^{\circ} 67$, p. 96 (destacado original).

${ }^{71}$ GRISOLÍA, "Nota", cit. nota n ${ }^{\circ}$ 67, p. 97 (destacado original).

${ }^{72}$ GRISOLÍA, "Nota", cit. nota n ${ }^{\circ}$ 67, p. 97 (destacado agregado).

${ }^{73}$ GRISOLÍA, "Nota", cit. nota n ${ }^{\circ}$ 67, p. 97 y s. 
ROJAS, Luis Emilio. "Deconstrucción del modelo dominante de comprensión de los delitos de falsedad documental".

Este análisis significa un claro avance en la aproximación al injusto propio del delito de falsedad documental. Por la simple razón de que intenta esclarecer el injusto del delito siguiendo el método que la dogmática habitualmente aplica en la parte especial, cual es, a partir de una tesis sobre el bien jurídico protegido. Y no salta inmediatamente a la cuestión del deber especial que tendría solamente el funcionario público. En ese sentido, este análisis parte de la premisa que dicho bien jurídico radica en el valor probatorio del documento y luego, en base a una interpretación sistemática del art. 1700 en relación con el art. 17 del Código civil, diferencia grados de eficacia probatoria del documento. El máximo grado de eficacia probatoria concurre en las declaraciones de ciencia emitidas por el funcionario público y que se encuentran dotadas de una certeza jurídica de verdad. Un menor grado de eficacia concurre en las declaraciones de ciencia y de voluntad emitidas por el particular, ya que gozan de una mera presunción de sinceridad o verdad. En este punto, Grisolía recurre a la cuestión del deber de veracidad y, al mismo tiempo, su análisis se torna equívoco. Porque una diferenciación que en principio era cuantitativa sorpresivamente se vuelve cualitativa y traza la frontera entre injusto y no injusto. Así, la máxima eficacia probatoria de las declaraciones de ciencia emitidas por el funcionario público que gozan de una certeza jurídica de verdad pertenece al "complejo de valores", a cuya protección tiende la norma del art. 193 en sus modalidades de falsedad ideológica. En cambio, la menor eficacia probatoria de las declaraciones de ciencia y de voluntad emitidas por el particular que se encuentran dotadas de una mera presunción de sinceridad o verdad, no revisten "tan grave trascendencia probatoria" que justifique su protección mediante la norma en esas mismas modalidades.

Pero, que estas declaraciones tengan menor eficacia probatoria por la mera presunción de sinceridad o verdad, no significa que no tengan ninguna eficacia; que no sean de tanta trascendencia probatoria no implica que no tengan ninguna relevancia. En rigor, a partir del concepto de bien jurídico que Grisolía propone se sigue más bien que dicha menor eficacia probatoria de las declaraciones de un particular, vertidas en un documento público, sí pertenece al "complejo de valores" protegido mediante esta misma norma. Desde este punto de vista, podría argumentarse que si bien es cierto que en estas declaraciones dotadas de tal presunción existe un interés probatorio digno de ser protegido, correlativamente el particular no tiene ningún deber de veracidad. ${ }^{74}$ Sin embargo, frente a este argumento tendría que advertirse que tampoco respecto del funcionario público existe norma alguna que expresamente le imponga un deber de decir verdad. Este deber es más bien implícito y correlativo a la máxima eficacia probatoria de las declaraciones de ciencia del funcionario público. En consecuencia, tendría más bien que aceptarse la existencia también implícita de tal deber correlativa a la menor, aunque no inexistente, eficacia probatoria de las declaraciones de ciencia y de voluntad de los particulares.

De este modo, la propuesta de Grisolía, basada en una interpretación del art. 1700 CC, si bien significa un notorio avance en el esclarecimiento del injusto del delito en las

\footnotetext{
74 Así GRISOLÍA, "Nota", cit. nota n 67, p. 98: "en Chile no existe norma expresa alguna que imponga semejante deber", que al referirse a Chile lo hace por contraste con la legislación extranjera, por ejemplo, el art. 483 CP italiano y el art. 293 del CP argentino (nota 12 que remite a nota 8), esto es, leyes penales que sí impondrían tal deber al particular.
} 
modalidades de falsedad ideológica, no logra salir de la circularidad de la argumentación expuesta precedentemente.

\subsubsection{Propuestas de reformulación teórica en la doctrina española}

Tampoco logran escapar de esta argumentación circular las propuestas más recientes formuladas en la doctrina española. Así, García Cantizano parte de una aproximación crítica a la distinción entre falsedad material e ideológica, al decir que "representa una construcción del delito de falsedad documental más teorizante que práctica" y que los intentos para obtener criterios claros de diferenciación de un supuesto de otro no han pasado de ser buenas intenciones carentes de un contenido sustancial. ${ }^{75}$ Una distinción que no es capaz de diferenciar debería derechamente abandonarse. No obstante, al analizar luego las modalidades de comisión del delito de falsedad documental descritas en el art. 390 del CP español respecto del funcionario público y en el art. 392 del mismo código respecto del particular, esa distinción cobra una relevancia en la interpretación de los tipos desproporcionada en relación a la crítica formulada. Así, la modalidad del art. 390 que afecta al contenido verídico de la declaración documental $\left(4^{\mathrm{a}}\right)$, cuando es cometida por el funcionario público, no radica únicamente en faltar a la verdad en la narración de los hechos, sino que "en realidad se concreta en el empleo ilegítimo de su potestad de autentificación", mediante el cual dota de especiales efectos probatorios a un documento público falso. ${ }^{76}$ Respecto de la misma modalidad (4a), cuando es cometida por el particular, el art. 392 excluye su aplicación, lo cual se considera justificado, puesto que no se constata en esa hipótesis "una efectiva lesión del bien jurídico protegido en el delito de falsedad documental". 77 Se critica la modalidad $3^{\mathrm{a}}$ del art. 390 ("Suponiendo en un acto la intervención de personas que no la han tenido, o atribuyendo a las que han intervenido en él declaraciones o manifestaciones diferentes de las que hubieran hecho"), que sí resulta aplicable al particular por remisión del art. 392 CP español, pues se trataría de una hipótesis de falsedad ideológica, por lo que debería interpretarse de manera restrictiva, "según la cual tales conductas sólo tienen cabida en el ámbito específico de la labor desarrollada por ciertos funcionarios y autoridades". 78 Aquí es posible observar el mismo movimiento argumentativo de recurrir al status especial del funcionario para explicar el injusto de una modalidad de falsedad documental cometida por un particular.

En la misma línea, Villacampa Estiarte, luego de analizar la distinción entre falsedad material e ideológica desde su origen en el Code Pénal francés y hasta su desarrollo principalmente en el ámbito de la doctrina italiana, llega a la conclusión que en el Código penal español "no se hace mención expresa alguna en su articulado a los conceptos de

\footnotetext{
${ }^{75}$ GARCÍA CANTIZANO, Falsedades documentales, cit. nota n ${ }^{\circ}$, p. 108 y s.

${ }^{76}$ GARCÍA CANTIZANO, Falsedades documentales, cit. nota ${ }^{\circ}$ 9, p. 109 y s., en base al ejemplo del funcionario del Registro de Propiedad que inscribe un inmueble bajo un nombre distinto del dueño que aparece en la escritura pública.

77 “Art. 392 CP: 1. El particular que cometiere en documento público, oficial o mercantil, alguna de las falsedades descritas en los tres primeros números del apartado 1 del artículo 390, será castigado con las penas de prisión de seis meses a tres años y multa de seis a doce meses"; GARCÍA CANTIZANO, Falsedades documentales, cit. nota $\mathrm{n}^{\circ} 9$, p. 112, en base al ejemplo de un particular que declara un precio de compra inferior del realmente pagado, en una escritura pública de compraventa.

${ }^{78}$ GARCÍA CANTIZANO, Falsedades documentales, cit. nota nº 9, p. 113.
} 
ROJAS, Luis Emilio. “Deconstrucción del modelo dominante de comprensión de los delitos de falsedad documental".

falsedad material o ideológica", por lo que "puede perfectamente prescindirse de tal diferenciación". 79 De ahí que esta autora, en lugar de esta distinción, proponga una interpretación del art. $390 \mathrm{CP}$ español en base a la teoría de las funciones. ${ }^{80}$ Respecto de la modalidad $3^{a}$ de este tipo, cuando es cometida por particulares, recuerda que "los particulares no pueden nunca, por principio, emitir documentos públicos u oficiales, porque no están investidos de fe pública ni son depositarios de la función certificadora del Estado", por lo que cuestiona que esta modalidad diga relación con la función probatoria del documento. En la hipótesis en que el sujeto atribuye a los intervinientes declaraciones que no han efectuado, Villacampa Estiarte sostiene que, si bien el documento es auténtico por coincidir el autor real y el autor aparente del mismo - por lo que "no se afecta estrictamente la función de garantía" -, contiene "declaraciones inauténticas", en consecuencia, esta modalidad tendría una "naturaleza híbrida". ${ }^{81}$ Similar interpretación propone respecto de la otra modalidad - "suponiendo en un acto la intervención de personas que no la han tenido" - contemplada en el mismo numeral $3^{\circ}$ del art. 390. ${ }^{82}$ No obstante, el art. 395 del CP español, sobre falsificación de documentos privados, remite también a esta modalidad $3^{\text {a }}$ del art. 390, lo cual abre "una puerta falsa a la posibilidad de sancionar la falsedad ideológica en documentos privados". 83 Dado que estos documentos no gozarían de fuerza probatoria, la realización de esta modalidad no podría afectar la función probatoria. Frente a la tendencia expansiva que Villacampa Estiarte detecta en la jurisprudencia española, propone una interpretación restrictiva, según la cual esta modalidad $3^{a}$ solamente podría realizarse respecto de aquellos particulares que se encuentran sujetos a "deberes fedatarios" análogos a los del funcionario público. ${ }^{84}$

La propuesta interpretativa de Villacampa Estiarte es sumamente interesante, pues logra aproximarse al injusto del delito prescindiendo del binomio falsedad material / falsedad ideológica. Esta aproximación le permite relacionar la modalidad $3^{\mathrm{a}}$ del art. 390, que resulta aplicable por mandato del art. 392 tanto al particular que comete falsedad en documento público o mercantil como en virtud del art. $395 \mathrm{CP}$ español al que falsifica un documento privado, con la autenticidad de la declaración y no necesariamente con su contenido de verdad -que atañe a la función probatoria. Es decir, se trata de una propuesta interpretativa que busca esclarecer el injusto del delito en atención a la relevancia de las conductas tipificadas en el art. 390 para las funciones del documento. Así, sostiene que esta modalidad $3^{\mathrm{a}}$ tendría una "naturaleza híbrida" o mixta, pues atañe no solamente a la función probatoria, sino que afecta también a la autenticidad de la declaración, mas no del

\footnotetext{
${ }^{79}$ VILLACAMPA ESTIARTE, La falsedad documental, cit. nota ${ }^{\circ}$ 28, p. 347 y s.

${ }^{80}$ VILLACAMPA ESTIARTE, La falsedad documental, cit. nota $\mathrm{n}^{\circ} 28$, pp. 423 y ss.

${ }^{81}$ VILLACAMPA ESTIARTE, La falsedad documental, cit. nota ${ }^{\circ} 28$, p. 526 y s.

${ }^{82}$ VILLACAMPA ESTIARTE, La falsedad documental, cit. nota $\mathrm{n}^{\circ} 28$, pp. 532 y ss.

83 “Art. 395 CP: El que, para perjudicar a otro, cometiere en documento privado alguna de las falsedades previstas en los tres primeros números del apartado 1 del artículo 390, será castigado con la pena de prisión de seis meses a dos años"; GARCÍA CANTIZANO, Falsedades documentales, cit. nota n 9, p. 113.

${ }^{84}$ VILLACAMPA ESTIARTE, La falsedad documental, cit. nota $\mathrm{n}^{\circ}$ 28, p. 528, 531 y s., 541.; cabe señalar que esta propuesta constituye el desarrollo de una idea ya contenida en la monografía de GARCÍA CANTIZANO, Falsedades documentales, cit. nota $\mathrm{n}^{\circ}$ 9, p. 113: "en general, debería procederse a una interpretación estricta, según la cual tales conductas sólo tienen cabida en el ámbito específico de la labor desarrollada por ciertos funcionarios y autoridades. Más allá de estos límites, no tiene aplicabilidad esta disposición, en tanto en cuanto no pueda subsumirse bajo el tenor de las otras formas de ejecución del delito".
} 
documento. En la medida en que coinciden autor real y autor aparente, el documento sería auténtico - por lo que no se vería amagada la función de garantía-, aunque contendría declaraciones inauténticas. Esta afirmación solamente es posible bajo la premisa de un concepto de documento, según el cual éste es algo distinto de la declaración que contiene. Si en cambio se suscribe la teoría de la declaración ${ }^{85}$, según la cual documento es una declaración fijada, entonces, en esa parte el documento se vuelve falso por contener una declaración que no ha sido emitida por quien aparece en él otorgándola. Sin embargo, el texto de la modalidad $3^{\mathrm{a}}$ del art. 390, que utiliza la forma gramatical del gerundio "suponiendo" o "atribuyendo" -, al igual que el art. 193 N. 2 y N. 3 CP, es leído como si describiera la conducta típica en la forma gramatical del infinitivo -"suponer" o "atribuir". Por eso se vincula esta modalidad con la del N. 4 del art. 390 CP español, que es reconocidamente una hipótesis de "falsedad ideológica". Porque si el texto de esta modalidad $3^{a}$ es leído con el infinitivo "suponer" o "atribuir", donde utiliza el gerundio de ambos verbos, entonces la frase que describe la conducta prohibida es leída como "suponer" en un acto la intervención de personas que no la han tenido o "atribuir" a las que han intervenido en él declaraciones o manifestaciones diferentes de las que hubieren hecho, es decir, como una declaración falsa, contrapuesta a la verdad y que afectaría la función probatoria del documento. Por eso, se habla de una naturaleza "híbrida" de esta modalidad $3^{\mathrm{a}}$, que afectaría tanto a la autenticidad como a la función probatoria del documento. Y, en la parte que atañe a esta última función, como presupone que el documento tenga fuerza probatoria, se propone una interpretación restrictiva, que limita el ámbito de aplicación de esta modalidad $3^{\mathrm{a}}$ solamente a aquellos sujetos dotados de "deberes fedatarios" análogos a los del funcionario público. En definitiva, nuevamente se recurre al status especial del funcionario público para delimitar el injusto del delito de falsedad documental.

Recientemente, Enrique Bacigalupo ha propuesto reformular consciente y explícitamente la distinción entre falsedad material y falsedad ideológica como un problema relativo a los deberes: "si el problema del autor de la falsedad se contempla más profundamente, se revela de inmediato que se trata de un problema de deberes que incumben a ciertos sujetos". ${ }^{86}$ Sostiene la tesis que la mutatio veritatis no es un concepto único, en el sentido de que la "verdad" no es la misma en los documentos públicos y en los documentos privados. $^{87}$ Esto implica que la función probatoria de ambas clases de documentos es diferente, pues mientras los documentos públicos prueban la verdad de los hechos y declaraciones documentadas por el oficial público, el efecto probatorio de los documentos privados no alcanza a la verdad de lo declarado por el particular. ${ }^{88}$ Así, sólo la falsificación de documentos públicos puede ser concebida como un delito contra la fe pública, mientras que la falsificación de documentos privados sólo constituye "un delito contra los medios de prueba". Dicho de otro modo: "la 'verdad' de los documentos privados es lo que garantizan, es decir, se reduce a su autenticidad". ${ }^{89}$ La autenticidad del documento puede ser afectada de la misma manera en un documento público y en un documento privado, "se trata siempre de una falsedad material", que, entonces, puede realizarse tanto respecto de

\footnotetext{
${ }^{85}$ Cfr. respecto de esta teoría ROJAS, "Falsedad documental como delito de engaño", cit. nota $n^{\circ} 50$.

${ }^{86}$ BACIGALUPO, Falsedad documental, cit. nota ${ }^{\circ}$ 62, p. 27 (destacado original).

${ }^{87}$ BACIGALUPO, Falsedad documental, cit. nota ${ }^{\circ} 62$, p. 100.

${ }^{88}$ BACIGALUPO, Falsedad documental, cit. nota ${ }^{\circ} 62$, p. 100 y s.

${ }^{89}$ BACIGALUPO, Falsedad documental, cit. nota $\mathrm{n}^{\circ}$ 62, p. 101 (destacado original).
} 
ROJAS, Luis Emilio. "Deconstrucción del modelo dominante de comprensión de los delitos de falsedad documental".

documentos públicos, caso en el cual se atacaría a la fe pública, como respecto de documentos privados, en cuyo caso se afectaría a los "medios de prueba". ${ }^{90}$ En virtud de estas consideraciones, este autor propone una nueva sistematización de los delitos de falsedad documental. Los delitos contra los medios de prueba, que pueden ser cometidos por todos y que, por lo tanto, serían delitos comunes de falsedad documental. Este grupo se estructuraría sobre la base de la infracción a un deber de no alterar la autenticidad de un documento, sea público o privado: "este deber protege al documento en tanto medio de prueba, pero no impone decir siempre la verdad. No se trata del deber de decir verdad, sino del deber de no perjudicar la prueba de determinados hechos". 91 De este grupo se distingue un "delito especial de funcionarios, que afectaría directamente a la fe pública y que sería, en principio, un delito de falsedad ideológica". Este delito se fundaría "en la infracción de un deber de documentar verazmente, hechos o declaraciones relevantes para derechos o relaciones jurídicas; es decir, la infracción de un deber de veracidad". Se trataría de un deber institucional que alcanzaría "no sólo a las falsedades ideológicas, sino también a las falsedades materiales con las que el funcionario pudiera alterar un documento público de su competencia ya perfeccionado". 92

La reformulación teórica propuesta por Bacigalupo es sumamente interesante, tanto en un plano epistemológico como en uno dogmático. En un plano epistemológico, porque aclara que el concepto de verdad es distinto en el documento público y en el documento privado. Mientras que en el documento público se trata de la verdad sobre los hechos y declaraciones fijadas por el funcionario público, en el documento privado la verdad se reduce a su autenticidad. En el plano dogmático, porque reformula una distinción más bien descriptiva, como es aquella entre falsedad material y falsedad ideológica, en términos normativos, esto es, a partir del significado de la conducta para ciertos deberes del sujeto. Así, el significado injusto de la falsedad material proviene de la infracción de un deber de no alterar la autenticidad de un documento, público o privado. Se trata, entonces, de un deber negativo -"responsabilidad por organización". En cambio, el significado injusto de la falsedad ideológica consiste en la infracción de un deber de veracidad. Se trata, en consecuencia, de un deber positivo -"responsabilidad institucional". ${ }^{33}$ Esta reformulación teórica implica un claro avance en el esclarecimiento del injusto de los delitos de falsedad documental. Porque explicita un nexo que hasta ahora ha quedado más bien preterido en la doctrina, cual es el vínculo existente entre autenticidad y documento público. También se puede realizar el injusto del delito de falsedad documental mediante una conducta que signifique una infracción del deber de no alterar la autenticidad de un documento público. Lo que ocurre es que, además, existe un nexo entre verdad y documento público, porque la verdad sobre los hechos y las declaraciones fijadas solamente se garantiza normativamente en esta clase de documentos. Dicha verdad es correlativa a un deber positivo de veracidad, ergo, el injusto de este delito puede realizarse, primero, mediante la infracción del deber negativo relativo a la autenticidad del documento público y, segundo, mediante la infracción del deber positivo relativo a la verdad del mismo documento. En cambio, ya que

\footnotetext{
${ }^{90}$ BACIGALUPO, Falsedad documental, cit. nota ${ }^{\circ} 62$, p. 101 y s.

${ }^{91}$ BACIGALUPO, Falsedad documental, cit. nota ${ }^{\circ} 62$, p. 102 y s.

${ }^{92}$ BACIGALUPO, Falsedad documental, cit. nota ${ }^{\circ}$ 62, p. 103.

${ }^{93}$ Cfr. JAKOBS, Strafrecht, cit. nota ${ }^{\circ}$ 4, Apdo. 29, núm. marg. 14-16, el fundamento de la responsabilidad deriva de la competencia por organización o de la competencia institucional.
} 
la "verdad" del documento privado se reduce a su autenticidad, entonces, el injusto del delito puede realizarse solamente mediante la infracción del deber negativo de no alterar la autenticidad del documento privado.

El problema de esta reformulación teórica es que no logra resolver bien la relación entre el plano epistemológico y el dogmático. Pues incurre en el mismo problema metodológico de relacionar una cuestión relativa al injusto del delito, como es la distinción entre un delito contra los medios de prueba, cuyo injusto deriva de la infracción de un deber de no alterar la autenticidad del documento, y un delito contra la fe pública, cuyo injusto deriva de la infracción de un deber de veracidad, con una distinción propia de la teoría de la autoría y la participación como es aquella entre un delito común y un delito especial -de infracción de deber. Este paso metodológico implica que el delito contra los medios de prueba, al que se acota la falsificación de documentos privados, puede ser realizado por cualquiera, en cambio, el delito contra la fe pública, restringido a la falsificación de documentos públicos, solamente puede ser realizado por el funcionario público. Sin embargo, Bacigalupo aclara que el deber institucional del funcionario público abarca también la falsedad material que éste puede cometer en un documento público, resultando afectada en esa hipótesis indirectamente la fe pública. En este punto, la tesis ya no es de recibo. ¿Por qué la falsedad material cometida por un funcionario público alterando la autenticidad del documento público es un delito contra la fe pública y no contra los medios de prueba? Si ya se había aclarado que el deber de no alterar la autenticidad rige por igual en un documento privado o público, ¿por qué la infracción de este deber por parte de un particular configura un delito contra los medios de prueba y la infracción del mismo deber por parte de un funcionario público configura un delito contra la fe pública? Lo coherente sería sostener que la infracción del deber de no alterar la autenticidad de un documento público cometida por un funcionario público es también un delito contra los medios de prueba, pero agravado por los deberes especiales de este sujeto activo.

Pero, aquí nuevamente se recurre al status especial del funcionario público para sostener la configuración de un delito distinto por la intervención del sujeto activo. Donde constituye un aporte, la propuesta revela al mismo tiempo su límite. No obstante haber esclarecido la base epistemológica para la reconstrucción dogmática de los delitos de falsedad documental. Esta base radica en la distinción operada en el concepto de verdad. La verdad es distinta en el documento privado y en el documento público, por lo tanto, su mutación configura un injusto también distinto del delito de falsedad. La "verdad" del documento privado se reduce a su autenticidad, es decir, respecto de los documentos privados se protege normativamente solamente su autenticidad. Correlativamente, existe un deber de no alterar la autenticidad del documento privado, que puede ser infringido por cualquiera, en tanto se trata de un deber negativo. La "verdad" así comprendida, esto es, reducida a la autenticidad, es igualmente constitutiva de un documento privado o público. Respecto de los documentos públicos también se protege normativamente su autenticidad. Correlativamente, también existe un deber de no alterar la autenticidad de un documento público, que puede ser infringido por cualquier sujeto, particular o funcionario público. En cambio, el concepto de verdad en el documento público es distinto, porque, además de la autenticidad, aquél abarca la verdad sobre los hechos y declaraciones fijadas en el mismo. Más precisamente, se trata de la verdad como correspondencia entre declaración y hecho 
ROJAS, Luis Emilio. "Deconstrucción del modelo dominante de comprensión de los delitos de falsedad documental".

externo. $^{94}$ La verdad así comprendida, sin comillas, es constitutiva solamente del documento público. Solamente respecto de los documentos públicos se garantiza normativamente su verdad, por la intervención del funcionario público que precisamente convierte el documento en público. Correlativamente, nace un deber de decir verdad. Pero, de este razonamiento no se sigue que este deber solamente pueda ser infringido por el funcionario público, dando origen a un injusto del delito por la creación de un documento público falso en el sentido de que su declaración no se corresponde con un hecho externo. Si la verdad así comprendida se asocia al contexto específico de otorgamiento de un documento público, por la intervención de un funcionario público, entonces su protección se legitima frente a cualquier sujeto, desde ya ante al mismo funcionario público, pero también frente al particular, en la medida en que éste intervenga en el mismo contexto de otorgamiento del documento público. Dicho en el código del "bien jurídico": si existe un interés en la protección de la verdad, que nace solamente del contexto de otorgamiento de un documento público, entonces dicho interés puede ser vulnerado tanto mediante una conducta de falsedad del funcionario público como mediante una de falsificación del particular. Reformulado en clave de deberes: si el deber de decir verdad surge del contexto de otorgamiento de un documento público, entonces dicho deber puede ser infringido tanto por el funcionario público como por el particular que interviene en ese contexto, dando origen al mismo injusto del delito de falsedad documental.

\subsection{Cuarta dicotomía: delito especial / delito común - autoría y participación}

La forma en que la doctrina se aproxima críticamente a la hipótesis de "falsedad ideológica", cuando es cometida por un particular en un documento público, deja entrever la razón por la cual se argumenta en base a distinciones más bien propias de hipótesis de pluralidad de intervinientes. La explicación radica en que el otorgamiento de un documento público en que interviene un particular presupone la concurrencia de un funcionario público y de al menos un particular. De la pluralidad de sujetos que interviene en el otorgamiento de un documento público, la doctrina colige la pluralidad de intervinientes en la realización del injusto. Sin embargo, la pluralidad de intervinientes en el injusto no está necesariamente asociada al otorgamiento de un documento público. Desde ya en el supuesto de verdad, esto es, en el contexto normal de otorgamiento de un documento público, en que interviene un funcionario y al menos un particular, surge regularmente un documento público auténtico y verdadero. Pero, en el supuesto contrario de falsedad, es posible que solamente uno de los intervinientes realice el injusto, sin que el otro participe en el mismo, por ejemplo, un funcionario declara falsamente que han concurrido el particular A y el particular B al

\footnotetext{
${ }^{94}$ Cfr. el saludable rescate del concepto de verdad como correspondencia en SEARLE, John, La construcción de la realidad social, Barcelona/Buenos Aires/México: Paidos, 1997, p. 77: "un hecho es independiente del lenguaje si el hecho mismo no necesita de elementos lingüísticos para su existencia. Borren todo el lenguaje y el monte Everest seguirá teniendo nieve y hielo en su cúspide; borren todo el lenguaje y habrán borrado también el hecho de que 'El monte Everest tiene hielo y nieve en la cúspide' es una sentencia castellana"; ver esquema de los hechos en p. 132 (hechos físicos brutos y hechos intencionales, dentro de los cuales incluye los hechos sociales y los institucionales); en rigor, esta tesis realista es "consistente con cualquier teoría de la verdad, porque es una teoría de la ontología, no una teoría del significado de "verdadero"” (p. 163); no obstante, Searle, frente a varias tendencias filosóficas en boga, recupera la teoría de la verdad como correspondencia, así la sentencia: “'la nieve es blanca' es verdadera si y sólo si la nieve es blanca" (p. 205); “'hecho' se define meramente como aquello en virtud de lo cual un enunciado es verdadero (...)" (p. 216).
} 
otorgamiento de un documento público, cuando en verdad no ha concurrido ni A ni B a este acto. En el ejemplo inverso, el particular A declara falsamente ser C y el particular B declara falsamente ser $\mathrm{D}$, ambos de consuno ante el funcionario que otorga el documento público bajo el error de creer que $\mathrm{A}$ es $\mathrm{C}$ y que B es D. En el primer supuesto de falsedad, solamente el funcionario realiza el injusto del delito por la creación de un documento público falso, simplemente porque ni A ni B han otorgado dicho documento. En el ejemplo inverso, solamente A y B realizan el injusto del delito por la creación de un documento público inauténtico, simplemente porque ni $\mathrm{C}$ ni $\mathrm{D}$ han concurrido a otorgarlo. Pero, el funcionario, en este segundo supuesto de falsedad, no realiza el injusto del delito ni participa en el que realizan tanto A como B. Por lo tanto, no siempre la pluralidad de sujetos que interviene en el otorgamiento de un documento público se traduce en una pluralidad de intervinientes en el injusto del delito de falsedad documental.

Ergo, metodológicamente resulta aconsejable transitar el mismo camino que la doctrina sigue al analizar cualquier delito contemplado en la parte especial del Derecho penal. Esto es, primeramente analizar los elementos y requisitos típicos del delito en cuestión, para luego esclarecer, si se trata de un delito especial o común, para los efectos de la aplicación de las reglas sobre autoría y participación en hipótesis de pluralidad de intervinientes en la realización del injusto. No obstante, en materia de los delitos de falsedad documental, como ya se ha mostrado (supra 2.3), la doctrina se desvía de ese camino. En un primer paso, aclara que la falsedad ideológica es un delito especial, porque solamente puede ser cometida por un funcionario público, mientras que la falsedad material es un delito común, puesto que puede ser cometida por cualquiera. ${ }^{95}$ Esta aclaración se formula en relación al tipo del art. $193 \mathrm{CP}$, en cuyo encabezado se exige que se trate de un empleado público, además que comete falsedad "abusando de su oficio". Esto es, se trata de un tipo que establece un delito especial, pues exige una calidad especial respecto del sujeto activo. Sin embargo, la lectura que relaciona las modalidades de falsedad ideológica (N. 2, 3, 4 y 7) con un delito especial y las modalidades de falsedad material (N. 1, 5 y 6) con un delito común, implica que, en contra del texto del encabezado, el mismo tipo contiene dos delitos diferentes: un "delito especial de falsedad ideológica" y un "delito común de falsedad material". Otro tanto ocurre respecto del tipo del art. 194 CP. Su texto reza: "el particular que cometiere en documento público o auténtico alguna de las falsedades designadas en el artículo anterior", ergo, conforme a su letra se trata de un delito común. Sin embargo, la doctrina recurre a la misma distinción, para sostener, en contra del texto expreso que remite a cualquiera de las "falsedades descritas en el artículo anterior" (art. 193), que dicho sujeto activo solamente puede realizar las modalidades de falsedad material: "pero esta referencia no es absoluta, por cuanto un particular no puede ejecutar todas las conductas descritas en la referida disposición legal. Deben marginarse aquellos comportamientos que importen falsedad ideológica (...)".96 La remisión expresa del art. 194 a las "falsedades designadas" en el art. 193 abarca tanto las modalidades de falsedad material (N. 1, 5 y 6) como las modalidades de falsedad ideológica (N. 2, 3, 4 y 7). Contra el texto expreso del art. 194, esta lectura del mismo incluye en la remisión solamente las modalidades de falsedad

\footnotetext{
${ }^{95}$ GARRIDO, Derecho penal, cit. nota ${ }^{\circ}$ 6, p. 63; ETCHEBERRY, Derecho penal, cit. nota ${ }^{\circ}$ 5, p. 168 ; POLITOFF/MATUS/RAMÍREZ, Lecciones de Derecho penal, cit. nota n ${ }^{\circ}$ 5, pp. 561-567.

${ }^{96}$ GARRIDO, Derecho penal, cit. nota ${ }^{\circ}$ 6, p. 82; ETCHEBERRY, Derecho penal, cit. nota ${ }^{\circ}$ 5, p. 169 ; POLITOFF/MATUS/RAMÍREZ, Lecciones de Derecho penal, cit. nota n ${ }^{\circ}$ 5, pp. 563-564.
} 
ROJAS, Luis Emilio. "Deconstrucción del modelo dominante de comprensión de los delitos de falsedad documental".

material y excluye las de falsedad ideológica. La razón de esta exclusión contra legem radicaría en que el particular, por regla general, no tiene el deber de decir verdad. Pero, el texto expreso del art. 194, a diferencia de aquel del art. 193, no exige ninguna calidad especial respecto del sujeto activo como presupuesto de aplicación de la norma del art. 194 CP. En consecuencia, esta lectura de la ley penal exige una calidad especial respecto del sujeto activo más allá e incluso en contra del texto expreso del art. 194 CP.

Esta calidad especial del sujeto activo, no contemplada en el texto expreso, se erige como presupuesto de la sanción penal en casos en que el particular comete modalidades de falsedad ideológica. Estos casos, sin embargo, al quedar excluidos del tipo del art. 194, tendrían que contemplarse, según este razonamiento, en otras leyes penales. Esto es, la razón por la cual se excluyen estos casos de la norma del art. 194 consistiría en que el particular, por regla general, no tiene un deber de decir verdad. Esta regla general tendría excepciones. La doctrina nacional menciona dos excepciones: el art. 27 de la Ley 4.808, sobre Registro civil ("El que en escritura pública suministrare maliciosamente datos falsos sobre un estado civil, sufrirá las penas que el Código penal aplica al que faltare a la verdad en la narración de hechos substanciales en documento público") y el art. 59 de la Ley 18.840, orgánica constitucional del Banco Central. ${ }^{97}$ Sin embargo, la excepción del art. 27 de la Ley sobre registro civil, a su turno, remite a las penas que el Código penal contempla por la realización de una modalidad paradigmática de falsedad ideológica. La pregunta que surge a continuación es: ¿cuáles penas? ¿la del art. 193 N. 4 o la del art. 194 CP? No podría tratarse de la pena contemplada en el art. $193 \mathrm{CP}$, pues éste expresamente exige la calidad especial del sujeto activo como presupuesto de la sanción allí prevista. Se trata, entonces, de la pena contemplada en el art. 194 CP. De esta manera, se cierra el círculo. Según esta argumentación, la norma del art. 194 CP contempla una sanción penal por la realización de dos delitos diferentes. Un "delito de falsedad material" en la parte del texto que remite a estas modalidades descritas en los numerales 1, 5 y 6 del art. 193 CP. Se trataría de un delito común, por lo que cualquiera puede realizarlo. Y un "delito de falsedad ideológica" en la parte del texto que remite a esta clase de modalidades designadas en los numerales 2 , 3, 4 y 7 del art. 193 CP. No se trataría de un delito común, sino que de un delito especial, que exigiría la concurrencia de una calidad especial no contemplada expresamente en el texto mismo del art. $194 \mathrm{CP}$, sino que en el texto de otra ley penal, como por ej. art. 27 de la Ley sobre Registro civil. En conclusión, según esta lectura, el art. 194 CP es una norma "híbrida".

En la doctrina española, el problema se encuentra resuelto legislativamente en relación a la modalidad paradigmática de falsedad ideológica, descrita en el art. 390 N. 4: "faltando a la verdad en la narración de los hechos". Porque el art. 392 CP español, que resulta aplicable al particular que comete falsedad en documento público, oficial o mercantil, remite a las modalidades descritas en los numerales $1^{\circ}, 2^{\circ}$ y $3^{\circ}$, pero no a la designada en el N. 4 del art. 390 del mismo Código. El problema se presenta respecto de aquellas modalidades del

\footnotetext{
${ }^{97}$ Art. 59 de la Ley 18.840, orgánica constitucional del Banco Central: "La persona que incurriere en falsedad maliciosa en los documentos que acompañe en sus actuaciones con el Banco o en las operaciones de cambios internacionales regidas por esta ley, será sancionada por los tribunales de justicia con la pena de presidio menor en su grado medio a máximo", como puede verse se trata de una norma cuyo fin dice relación más bien con la protección de intereses colectivos involucrados en esa clase de operaciones, y no de la verdad como tal.
} 
art. 390, a las cuales se remite expresamente el art. 392, y que, según la doctrina, se superponen con la descrita en el numeral $4^{\circ}$, por tratarse de "variedades" de falsedad ideológica. ${ }^{98}$ Se trataría de las modalidades descritas en el numeral $2^{\circ}$ ("simulando un documento en todo o en parte, de manera que induzca a error sobre su autenticidad") y en el numeral $3^{\circ}$, que reúne en un mismo texto las modalidades descritas en el N. 2 y N. 3 del art. 193 CP. En rigor, el problema se evidenciaría como aparente respecto del numeral $2^{\circ}$ del art. 390, si en virtud de la referencia expresa que el texto hace a la "autenticidad", se interpretase su significado como vulnerador de la autenticidad del documento. Lo mismo sucedería respecto del numeral $3^{\circ}$ del art. 390, si se siguiera la interpretación expuesta (supra 2.3.2.), que reconduce su significado también como contrario a la autenticidad de la declaración. ${ }^{99}$ No obstante, la doctrina española admite que ambos numerales incluyen todavía hipótesis de falsedad ideológica, las que, en consecuencia, solamente serían punibles en la medida en que concurra el presupuesto propio de la modalidad paradigmática de falsedad ideológica descrita en el art. 390 N. 4 CP. En este sentido, se aclara que "esta forma de ejecución de la acción falsaria sólo tiene sentido en el marco del cumplimiento de una determinada función administrativa" y que "el marco donde se sitúa la actuación del sujeto viene caracterizada por el incumplimiento de la obligación de dar constancia fehaciente de ciertas situaciones, omitiendo precisamente su existencia". 100 "Pesa sobre él el deber de evitar una constatación falsa documental que es la que fundamenta su posición de garante y nos permite exigirle la correspondiente responsabilidad por delito de falsedad documental". ${ }^{101}$ Este razonamiento se volvería relevante para la solución de hipótesis de pluralidad de intervinientes en la realización del delito, por ejemplo, A, que es Notario, falsifica junto a $\mathrm{B}$, que es particular, en eventual coautoría un testamento en lugar del causahabiente y en favor de un testaferro de B. Para solucionar esta hipótesis, la doctrina española constata que el tipo del art. $390 \mathrm{CP}$ describe un delito especial y luego analiza si se trata de un delito especial propio o impropio. Si se trata de un delito especial propio, entonces el particular no podría ser autor del delito descrito en el art. 390, "aplicándose lo dispuesto en el art. 392 CP". ${ }^{102}$ En cambio:

"si se entiende que es un delito especial impropio, el particular que junto con el funcionario o autoridad también disfrutara del dominio del hecho, sería responsable en calidad de coautor, sancionándose su conducta según lo dispuesto en el art. $392 \mathrm{CP}$, en tanto que el funcionario respondería por el art. $390 \mathrm{CP}$, cuya condición personal serviría a modo de agravación del injusto". 103

\footnotetext{
98 GARCÍA CANTIZANO, Falsedades documentales, cit. nota n ${ }^{\circ}$ 9, p. 117; cfr. ECHANO BASALDÚA, Juan Ignacio, “¿Falsedad ideológica de particular en escritura pública? (revisión de la doctrina jurisprudencial)", en: VV. AA., Estudios penales en memoria del profesor Agustín Fernández-Albor, Santiago de Compostela: Universidad de Santiago de Compostela, 1989, pp. 253 y ss., quien busca criterios extraídos de la efectiva lesión o puesta en peligro del bien jurídico para distinguir las "inveracidades" de particulares constitutivas de falsedad de aquellas que no lo son.

${ }^{99}$ Cfr. en este sentido BACIGALUPO, Falsedad documental, cit. nota $\mathrm{n}^{\circ} 62$, p. 28 y s.

${ }^{100}$ GARCÍA CANTIZANO, Falsedades documentales, cit. nota n ${ }^{\circ}$ 9, p. 117 y s.

${ }^{101}$ GARCÍA CANTIZANO, Falsedades documentales, cit. nota n ${ }^{\circ}$ 9, p. 118.

${ }^{102}$ GARCÍA CANTIZANO, Falsedades documentales, cit. nota n ${ }^{\circ}$ 9, p. 131.

${ }^{103}$ GARCÍA CANTIZANO, Falsedades documentales, cit. nota n ${ }^{\circ}$ 9, p. 132.
} 
ROJAS, Luis Emilio. "Deconstrucción del modelo dominante de comprensión de los delitos de falsedad documental".

La doctrina española se decanta por la tesis de que el art. 390, al igual que el anterior art. 302, cuyo texto era prácticamente idéntico al del art. $193 \mathrm{CP}$, es un delito especial propio, porque se diferencia del art. 392 en el requisito de que sea cometido por un funcionario en el ejercicio de sus funciones, lo cual, además, agrava "el contenido antijurídico del injusto". 104

Pero, como puede observarse, la argumentación expuesta se vuelve circular, lo que se evidencia en las consecuencias a las que conduce una u otra tesis. De acuerdo a dicho razonamiento, si el art. 390 es un delito especial propio, entonces el particular en la hipótesis antedicha no puede responder como coautor del delito descrito en el art. 390, por lo que sólo puede responder como partícipe, en calidad de inductor o cómplice, siendo castigado con la pena contemplada en el art. 392 CP. Si el art. 390 es un delito especial impropio, entonces el particular en la misma hipótesis sí puede responder como coautor del delito descrito en el art. 390, siendo castigado con la pena también del art. 392 CP. Es decir, en ambas tesis, la forma de intervención del particular sería distinta, pero la pena, en definitiva, la misma, cual es la contemplada en el art. 392 CP. La argumentación expuesta revela que se trata de un problema aparente. Porque la distinción entre delito especial propio e impropio se plantea particularmente en grupos de delitos que presuponen expresamente un status especial asociado a deberes, sin que se incluya una figura típica expresamente aplicable al particular que no ostenta tal status, por ejemplo, en los delitos funcionarios. En el delito de malversación de caudales públicos, por ejemplo, cometido en coautoría por un funcionario y un particular, este último responde como partícipe en el delito de malversación, si se trata de un delito especial propio, o responde como autor de otro delito común, si se trata de un delito especial impropio. Este no es el escenario que presenta el art. 390 en relación con el art. 392 CP español. El art. 390 CP es un delito especial, que sólo puede ser realizado por el sujeto activo que ostente la calidad especial expresamente contemplada en el texto. Y el art. 392 CP es un delito común, que puede, en consecuencia, ser cometido por cualquier sujeto, particular o incluso un funcionario público que no reúna el requisito propio del art. $390 \mathrm{CP}$, porque, por ejemplo, actúa fuera de su órbita de competencia. Cuando la doctrina española, no obstante, recurre al status especial contemplado en el art. 390 respecto del sujeto activo de este delito y lo erige como presupuesto de aplicación de la pena contemplada en el art. 392 al particular que comete falsedad en hipótesis de "falsedad ideológica", aún incluidas en las modalidades descritas en los números 2 y 3 del art. $390 \mathrm{CP}$, incurre en la misma argumentación circular de la doctrina nacional expuesta precedentemente. En las modalidades contempladas en los números 1 a 3 del art. 390, a que expresamente se remite el art. 392 aplicable al particular que comete falsedad, cuando se trata de hipótesis de "falsedad ideológica", esta lectura convierte, contra legem, en esa parte un delito común en un delito especial. En conclusión, el art. 392 del CP español sería también una norma "híbrida".

${ }^{104}$ GARCÍA CANTIZANO, Falsedades documentales, cit. nota $\mathrm{n}^{\circ}$ 9, p. 133; en este sentido, también VILLACAMPA ESTIARTE, La falsedad documental, cit. nota n 28 , pp. 547 y ss. 
Polít. crim. Vol. 9, № 18 (Diciembre 2014), Art. 6, pp. 477-520.

[http://www.politicacriminal.cl/Vol_09/n_18/Vol9N18A6.pdf]

\section{Esquema de consecuencias del modelo: "la fortuna de los prácticos y la desesperación de los científicos"}

El modelo de comprensión de los delitos tipificados en los artículos 193, 194 y 197 CP, previamente analizado, se cristaliza en una serie de consecuencias asistemáticas y paradójicas. Según este modelo de comprensión, el artículo 193 CP describe un delito funcionario. De hecho, la doctrina nacional sostiene que resulta aplicable el concepto de empleado público previsto en el art. $260 \mathrm{CP} .{ }^{105}$ En consecuencia, lo determinante no sería tanto la falsedad como tal realizada en el documento público o auténtico. Lo que configuraría el injusto del delito sería más bien la infracción de deberes funcionarios por parte del sujeto activo. El hecho de que nazca un documento público falso por sí mismo no sería determinante. Sería relevante en la medida en que evidencie un empleo abusivo de la potestad pública confiada en el funcionario. La desconfianza que generaría este abuso comportaría un peligro para el bien jurídico colectivo, a cuya protección estaría dirigida la norma del art. $193 \mathrm{CP}$. En un sutil movimiento argumentativo, la fe pública se vuelve función pública. La teoría de las funciones, en la forma en que ha sido comprendida por la doctrina española al interpretar el art. 390 CP de 1995, ha servido para reforzar este movimiento argumentativo (vid. supra 2.1.).

Según este modelo de comprensión, el art. 194 CP es una norma "híbrida". Sanciona con una misma pena dos delitos diferentes. Por una parte, un delito común de falsedad material cometida en un documento público o auténtico. Por otra parte, un delito especial de falsedad ideológica cometida en un documento público. Lo paradójico es que la pena contemplada en el art. 194 CP no resulta aplicable cuando el sujeto realiza simplemente la conducta descrita expresamente en su propio texto, como ocurre en cualquier tipo penal. Según este modelo, la falsedad ideológica cometida por el particular en un documento público sólo puede sancionarse cuando otra ley penal distinta del artículo 194 CP obliga al particular a decir la verdad. La consecuencia de este modelo es la exigencia de una condición imposible de cumplir. Porque no existe ninguna ley penal ni pre-penal que

${ }^{105}$ GARRIDO, Derecho penal, cit. nota ${ }^{\circ}$ 6, p. 79; ETCHEBERRY, Derecho penal, cit. nota ${ }^{\circ}$ 5, p. 206 y s.; POLITOFF/MATUS/RAMÍREZ, Lecciones de Derecho penal, cit. nota $n^{\circ} 5$, p. 557, sólo aludiendo al empleado público sin tomar partido acerca de si, por tal, se entiende el concepto del art. 260 del código punitivo; en la jurisprudencia, el parecer de los tribunales tiende a coincidir en definitiva con el concepto de empleado público al que alude el art. 260, sin embargo, dicha jurisprudencia lleva a entender que es relevante, pero no suficiente el ejercicio de funciones públicas para ser comprendido dentro del concepto de empleado público a que alude el art. $193 \mathrm{CP}$, ya que dichas funciones deben estar adscritas a un deber especial en materia documental; por lo anterior, no es posible aseverar que se aplica una interpretación automática y mecánica del art. 260 del Código Penal, sino que especificado para efectos de la falsedad documental, así SCS, "Contra Donato Toriello y Otros", casación en el fondo, resolución de 31/05/1950, en GT, Año 1950, $1^{\circ}$ semestre, sentencia 53, pp. 288 y ss., aplica derechamente el concepto del art. $260 \mathrm{CP}$ (considerandos $4^{\circ}$ a $7^{\circ}$ ); recientemente, SCS, Rol N. 2321-07, "Contra Cruz Lorenzen y otros", casación en el fondo, resolución de 19/05/2008, se remitió al art. 260 CP para efectos del análisis de los delitos de falsificación de instrumento público, fraude al fisco, uso malicioso de instrumento público y estafa (considerandos $42^{\circ}$ a $49^{\circ}$ ); SCS, Rol N. 2924-08, de 15/07/2009, “Contra M.C.A y G.D.B.”, condena a dichos imputados en carácter de funcionarios públicos, remitiéndose a las normas administrativas; excepcionalmente, SCA Valpo, "Contra Aspee González", consulta, resolución de primera instancia de 24/09/1964, RDJGT, año 1965, vol. 62, enero a julio, pp. 172 y ss. (considerando $7^{\circ}$ ), se manifiesta por una interpretación propia, aplicable al delito de falsedad documental en comento, respecto a aquel que se contempla para efectos administrativos y además del concepto señalado en el artículo $260 \mathrm{CP}$. 
ROJAS, Luis Emilio. "Deconstrucción del modelo dominante de comprensión de los delitos de falsedad documental".

obligue expresamente a un particular a decir la verdad en relación al otorgamiento de un documento público. Tampoco existe tal respecto de un funcionario público. Existen disposiciones en la legislación especial que ordenan castigar con la pena del art. 194 CP las falsificaciones cometidas en ciertos documentos, como por ejemplo, certificados de conformidad de exportaciones (art. 28 Ley 19.545), certificados de conformidad de productos hortofrutícolas (art. 10 Ley 19.282), certificados en el marco de la Ley de Pesca (art. 64E inc. $6^{\circ}$ Ley 18.892, art. 10 Ley 19.713). La técnica legislativa acuñada en estas disposiciones especiales pareciera responder más bien a la propia de una legislación complementaria, que extiende el ámbito de aplicación de la norma del art. 194 CP a otros documentos considerados de igual entidad que el documento público o auténtico al que refiere expresamente su texto. Este modelo de comprensión, sin embargo, convierte la existencia de estas leyes penales en presupuesto de aplicación de la ley igualmente penal del art. $194 \mathrm{CP}$ a hipótesis de falsedad ideológica cometidas por un particular en un documento público. Esta consecuencia puede tildarse al menos de paradójica. Explica el motivo de la solución a la que llega la Excma. Corte Suprema en el caso citado al inicio (supra 1.). Según esta solución, la falsedad ideológica del particular como tal no es punible. Como en el caso no resultaría aplicable otra ley penal que remita expresamente el art. 194 $\mathrm{CP}$, entonces, la falsificación del documento público sólo podría ser punible en la medida en que signifique la infracción de otra norma penal, como por ejemplo, la que prohíbe la estafa para proteger el patrimonio (art. $468 \mathrm{CP}$ ).

Por último, según este modelo de comprensión, el art. 197 CP describe un delito común de falsedad material en perjuicio del patrimonio de otro. Pero, la falsificación del documento privado como tal tampoco sería determinante, porque esta clase de documento por sí misma no sería relevante. El documento privado falsificado alcanzaría relevancia en la medida en que sirva de instrumento funcional al perjuicio patrimonial.

En resumen, este modelo de comprensión fracciona el sistema de normas de los artículos 193, 194 y 197 CP. Estas normas del Código penal tienen un denominador común. Describen la conducta prohibida a partir de la misma frase: "cometer falsedad en un documento". Así, el texto del art. 193 CP describe la conducta prohibida ya en su encabezado: "el empleado público que, abusando de su oficio, cometiere falsedad" y, luego, describe ocho (8) modalidades de comisión de la falsedad en un documento público o auténtico. Gramaticalmente, el verbo rector se inserta en el encabezado de la norma: "cometer falsedad". Las ocho modalidades de falsedad siguen la forma gramatical del gerundio: $1^{\circ}$ "contrahaciendo", $2^{\circ}$ "suponiendo", $3^{\circ}$ "atribuyendo", 4० "faltando", 50 "alterando", $6^{\circ}$ "haciendo", $7^{\circ}$ "dando" y $8^{\circ}$ "ocultando". Ergo, la conducta prohibida por la norma del art. 193 CP radica en "cometer falsedad" mediante alguna de las ocho (8) modalidades descritas en su texto. El art. 194 CP describe la conducta prohibida en los mismos términos: "el particular que cometiere en documento público o auténtico alguna de las falsedades designadas en el artículo anterior". Según el texto de esta norma, se prohíbe al particular "cometer falsedad" en un documento público o auténtico mediante alguna de las ocho (8) modalidades descritas en el art. 193 CP. El art. 197 CP describe la conducta prohibida en los mismos términos: "el que, en perjuicio de tercero, cometiere en instrumento privado alguna de las falsedades designadas en el artículo 193”. Según el texto de esta norma, la conducta prohibida es "cometer falsedad" en un documento privado 
mediante alguna de las ocho (8) modalidades descritas en el art. 193 CP. La diferencia que surge del texto del art. 197 CP dice relación con la exigencia de "perjuicio a tercero". Esta es la razón de texto que lleva a la doctrina nacional a sostener que se trata de un delito patrimonial. Pero, esta norma no prohíbe provocar un perjuicio patrimonial a otro mediante la falsificación de un instrumento privado. Su texto no reza: "el que defraudare a otro mediante la falsificación de un documento privado". Según el texto de la norma, se prohíbe cometer falsedad, "en perjuicio de otro", en un documento privado. Por lo tanto, la conducta prohibida por la norma del art. $197 \mathrm{CP}$ se encuentra descrita en el texto legal de la misma forma que en el art. 193 y en el art. 194 CP. El texto del art. 193, 194 y 197 CP comparte la misma forma de descripción de la conducta prohibida por la norma.

Esta misma técnica de legislación penal presupone un sistema de normas. Las normas de los artículos 193, 194 y 197 CP prohíben la falsedad documental. En clave moderna, tipifican delitos de falsedad documental. El texto de la ley penal establece un sistema de normas. Sin embargo, el modelo de comprensión previamente analizado (supra 2.), literalmente fracciona este sistema de normas. Según este modelo de comprensión, el art. 193 CP establece un delito funcionario y la norma encuentra su fundamento en la protección del correcto funcionamiento de la "administración pública documentaria". El art. 194 CP establecería un delito "híbrido", compuesto de falsificación material de documento público y de falsedad ideológica del mismo, cuya sanción se supeditaría a la existencia de otra ley penal. El fundamento de la norma del art. $194 \mathrm{CP}$ permanece en la obscuridad. Y, por último, el art. $197 \mathrm{CP}$ establecería un delito de falsedad material en perjuicio patrimonial de otro y la norma encontraría su fundamento en la protección del patrimonio. Es decir, donde la ley penal establece un sistema de normas, según este modelo de comprensión existen tres delitos diferentes: un delito funcionario $\left(1^{\circ}\right)$, un delito "híbrido" $\left(2^{\circ}\right)$ y un delito patrimonial $\left(3^{\circ}\right)$. Este modelo de comprensión, dominante en la doctrina y en la jurisprudencia, se sitúa al margen del texto de la ley penal. El texto de los artículos 193, 194 y 197 del Código penal establece delitos de falsedad documental. Leído el mismo texto con los anteojos del modelo dominante de comprensión se ven tres delitos esencialmente diferentes. Sin embargo, estos tres delitos existen solamente en el universo conceptual del modelo dominante de comprensión, mas no en el texto de la ley penal. La praxis del sistema penal debe colocarse estos anteojos para ver estos delitos y proceder a la aplicación de la ley penal en conformidad a este modelo. Pero, también puede ser invitada a leer el texto de la ley penal sin los anteojos del modelo dominante de comprensión y así volver a ver, tal como lo hizo el legislador penal originario, en el texto de la ley aquello que expresamente contempla: delitos de falsedad documental. Si la praxis del sistema penal se coloca los anteojos del modelo dominante de comprensión para ver delitos esencialmente diferentes en un mismo sistema de normas o vuelve a leer el texto de la ley penal que establece delitos de falsedad documental, queda abandonado a la decisión que más le plazca. Por eso, Quintano Ripollés en 1952 observaba que las normas sobre delitos de falsedad documental "hacen, a la vez, la fortuna de los prácticos y la desesperación de los científicos". ${ }^{106}$

${ }^{106}$ QUINTANO RIPOLLÉS, La falsedad documental, cit. nota n 53, p. 14. 
ROJAS, Luis Emilio. “Deconstrucción del modelo dominante de comprensión de los delitos de falsedad documental".

\section{Crítica al modelo dominante de comprensión de los delitos de falsedad documental y bases para la reconstrucción dogmática del sistema de normas}

El análisis desarrollado precedentemente del modelo dominante de comprensión de los delitos de falsedad documental ya contiene una crítica. Pues, la dogmática se plantea una tarea imposible de cumplir, cuando pretende analizar sin criticar. El análisis dogmático siempre se desarrolla desde una perspectiva crítica. El paso siguiente consiste en explicitar esta perspectiva. La crítica que se formula al modelo dominante de comprensión de los artículos 193, 194 y 197 CP es que fracciona un sistema de normas. A esta crítica subyace una tesis: los artículos 193, 194 y 197 CP establecen un sistema de normas. El denominador común de este sistema es la descripción de delitos de falsedad documental. El art. 193 CP no establece un delito funcionario. Esta negación deriva de una simple constatación sistemática del Código penal. El art. $260 \mathrm{CP}$ define el concepto de empleado público "para los efectos de este título (V) y del párrafo IV del título III" del Libro II del Código penal. El art. 193 se ubica en el párrafo IV del título IV de la parte especial del mismo código, por ende, para los efectos del delito allí descrito no resulta aplicable el concepto de empleado público definido en el art. $260 \mathrm{CP}$. El art. 193 no establece un delito funcionario, sino que describe textualmente un delito de falsedad cometido por un funcionario en un documento público o auténtico. El "abuso de su oficio" al que refiere el encabezado de la norma implica que la realización del delito allí descrito presupone la infracción de deberes funcionarios. Pero, el injusto del delito deriva de la falsedad cometida en un documento público o auténtico, no de dicha infracción de deberes. El art. $194 \mathrm{CP}$ no establece un delito "hibrido". Esta negación deriva de la remisión indistinta que el texto de esta norma hace a cualquiera de las modalidades designadas en el art. 193 CP. La remisión del art. 194 al art. 193 es indistinta, porque el texto del art. 193 CP no distingue entre falsedad material y falsedad ideológica. El art. $194 \mathrm{CP}$ describe textualmente un delito de falsedad cometido por un particular en un documento público o auténtico. El art. 197 no establece un delito patrimonial. Esta negación deriva de una simple constatación sistemática del Código penal. Una interpretación según la cual "perjuicio" en el texto de la norma del art. 197, ubicada en el párrafo V del título IV de la parte especial del Código penal, significa lo mismo que "perjuicio" en el texto de las normas de los artículos 468 y 473, insertos en el título IX sobre "delitos contra la propiedad" del mismo código, no es plausible desde un punto de vista sistemático. El art. $197 \mathrm{CP}$ describe textualmente un delito de falsedad cometido por cualquiera en un documento privado o mercantil. El injusto del delito proviene de la falsedad cometida en un documento privado o mercantil, en la medida en que el documento como tal sea relevante por tratarse precisamente de un documento. La exigencia de "perjuicio de tercero", contemplada en el texto de la norma, cumple una función heurística, en el sentido de recordar al aplicador de la norma de verificar que el documento privado falsificado sea efectivamente un documento. ${ }^{107}$ Porque si no se trata de un documento, entonces la falsedad cometida no configura el injusto del delito.

El ejercicio propuesto de re-lectura del texto de la ley penal conduce a la identificación de una prohibición común a los artículos 193, 194 y 197 CP. Si estas disposiciones del CP comparten la misma forma de describir la conducta prohibida, entonces la prohibición

${ }^{107}$ Cfr. ROJAS, "Falsedad documental como delito de engaño”, cit. nota n ${ }^{\circ} 50$. 
subyacente a estas normas es también común. La estructura de la norma es la misma. La norma común reza: está prohibido cometer falsedad en un documento. Esta prohibición surge de una lectura gramaticalmente correcta del texto de la ley penal. El modelo dominante de comprensión de estos delitos lee de una manera gramaticalmente incorrecta el texto de la ley. Porque en la parte en que se describen las modalidades de comisión, utilizando el texto legal la forma gramatical del gerundio, la doctrina y jurisprudencia sustituyen esta forma por la del infinitivo, así, por ejemplo, N. 2 del art. 193 "suponiendo la intervención de una persona en el acto" por "suponer la intervención de una persona en el acto". Esta forma gramaticalmente incorrecta de leer el texto de la ley penal gatilla en este modelo la creencia de que la conducta prohibida se encuentra descrita en cada numeral del art. 193 CP. Así, se llega a hablar del tipo del art. 193 N. 2 o se pregunta por el injusto de la falsedad ideológica. Pero, gramaticalmente, el verbo rector no se encuentra inserto en cada numeral del art. $193 \mathrm{CP}$, por lo que no se encuentra prohibido por la norma "suponer en un acto la intervención de una persona" o "faltar a la verdad en la narración sobre hechos sustanciales". Gramaticalmente, el verbo rector se inserta en el encabezado de la norma, con la frase "cometer falsedad". Ergo, la conducta prohibida por la norma radica en "cometer falsedad" suponiendo la intervención de una persona en el acto o faltando a la verdad sobre la narración de hechos sustanciales (art. 193 N. 2 o N. 4 CP). Como su denominación habitual así lo indica correctamente, los numerales del art. 193 CP solamente describen diversas modalidades de comisión de la falsedad. Pero, "cometer falsedad" en un documento, no las modalidades de comisión como tales, se encuentra prohibido.

Ahora bien, el haber esclarecido que los artículos 193, 194 y 197 describen delitos de falsedad documental, no implica que necesariamente el injusto de cada delito de falsedad sea el mismo. La estructura de la prohibición es la misma, pero el contenido de injusto puede ser distinto. Pues, el significado de la falsedad puede ser distinto en un documento público que en un documento privado. Si, como bien lo aclara Bacigalupo (supra 2.3.2.), la verdad en un documento público es distinta que la "verdad" en un documento privado, entonces su mutación mediante la falsedad también adquiere un significado injusto diferente. En la medida en que la "verdad" del documento privado se reduce a su autenticidad, entonces el significado injusto de la falsedad cometida en un documento privado también se reduce el carácter inauténtico del documento privado falso. Mientras que la verdad en el documento público abarca también la verdad como correspondencia entre declaración y hecho externo, entonces el significado injusto de la falsedad cometida en un documento público abarca también la discrepancia entre narración y hecho contenida en un documento público falso.

Llegados a este punto, el error en el cual se puede incurrir es creer que la autenticidad y la verdad se sitúan en un plano epistemológicamente distinto. Así, el modelo dominante de comprensión vincula la autenticidad con la forma y la verdad con el fondo del documento. Por eso, se habla, por ejemplo, de "formas de autenticidad". Ese error implica olvidar que se trata solamente de conceptos distintos de verdad. Relacionar la autenticidad con la forma y la verdad con el fondo del documento, además, no tiene asidero en el sistema normativo nacional. Esta duda epistemológica pudo haberla resuelto Grisolía ya en 1956, cuando propuso una teoría de la falsedad documental sobre la base de una interpretación sistemática del art. 1700 en relación con el art. 17 del Código civil. Sin embargo, su análisis 
ROJAS, Luis Emilio. "Deconstrucción del modelo dominante de comprensión de los delitos de falsedad documental".

quedó acotado a una propuesta de reformulación teórica basada en una interpretación del art. 1700, sin explicitar su relación con el art. 17 CC (supra 2.3.1.). Y es el propio art. 17 del Código civil el que entrega la clave para la solución de este problema epistemológico al definir autenticidad y distinguirla de una cuestión de forma:

"La forma de los instrumentos públicos se determina por la ley del país en hayan sido otorgados. Su autenticidad se probará según las reglas establecidas en el Código de Enjuiciamiento.

La forma se refiere a las solemnidades externas, y la autenticidad al hecho de haber sido realmente otorgados y autorizados por las personas y de la manera que en los tales instrumentos se exprese."

Según esta definición del Código civil, la autenticidad del documento no dice relación con aspectos formales del mismo, sino que con una cuestión de fondo. La autenticidad consiste en el hecho de haber sido el documento realmente otorgado por la persona que en el mismo se exprese. ${ }^{108}$ La autenticidad, según este concepto legal, es una forma de la verdad y, por ende, no es algo esencialmente diferente a ésta.

En base a esta distinción epistemológica, es posible proponer la siguiente reconstrucción dogmática del sistema de normas de los artículos 193, 194 y 197 CP. Este sistema describe delitos de falsedad documental. El art. 193 describe un delito de falsedad cometido en un documento público. Esta descripción abarca el injusto del delito que deriva de la creación de un documento público falso en el sentido de inauténtico, por no haber sido éste realmente otorgado por la persona que en el mismo se expresa como su otorgante. Este injusto puede realizarse en cualquier clase de documento público, ya sea que fije una "declaración de ciencia" - un "documento testimonial"-, como por ej. un certificado de nacimiento o defunción, o una "declaración de voluntad" - un "documento dispositivo"-, por ej. un testamento. Este injusto del delito puede cometerse mediante cualquiera de las modalidades designadas en $\operatorname{los}$ numerales $1^{\circ}, 2^{\circ}, 3^{\circ}, 5^{\circ}, 6^{\circ}$ y $7^{\circ}$ del art. $193 \mathrm{CP}$. Pero, además, por la referencia inequívoca a la verdad como correspondencia en la modalidad descrita en el N. 4 del art. 193 CP, este tipo abarca también el injusto del delito que deriva de la creación de un documento público falso en el sentido de que su declaración no se corresponde con un hecho externo. Este injusto del delito presupone, como ya lo había advertido brillantemente Grisolía en 1956 (vid. supra 2.3.1.), que el documento público fije una declaración, respecto de la cual pueda emitirse un juicio de verdad o falsedad en el sentido antedicho, esto es, de correspondencia o discrepancia entre narración y hecho externo, respectivamente. La doctrina alemana denomina a esta clase de documentos un documento testimonial, mientras que Grisolía habla de "declaraciones de ciencia". Este injusto no puede realizarse, en consecuencia, en un documento dispositivo público, vale decir, que fija meramente una "declaración de voluntad". Puesto que una declaración de voluntad no puede ser verdadera o falsa en el sentido antedicho. Ambos injustos del delito

\footnotetext{
${ }^{108}$ Se puede sostener, siguiendo a SEARLE, La construcción de la realidad social, cit. nota ${ }^{\circ} 94$, p. 97 y s., que la autenticidad es un hecho institucional, incluso el propio Searle recurre al ejemplo del documento: "Los mecanismos característicos de que nos servimos son actos de habla: escrituras, facturas de venta, papeles del registro, testamentos, etc.; y no es por azar que éstos reciban normalmente el nombre de 'instrumentos jurídicos'. En todos los casos se trata de funciones de status impuestas a actos de habla” (p. 98).
} 
de falsedad en documento público pueden ser cometidos por el funcionario. El art. $193 \mathrm{CP}$ describe un delito especial.

El art. 194 CP describe un delito de falsedad cometido en un documento público por un particular. La descripción de la conducta prohibida surge de una remisión a cualquiera de las modalidades de falsedad designadas en el art. 193 CP. Por ende, según el texto de la norma, la descripción abarca tanto el injusto en la forma de la creación de un documento público falso en el sentido de inauténtico como el que deriva de la creación de un documento público falso en el sentido de que su declaración no se corresponde con un hecho externo. El primer injusto del delito puede realizarse en cualquier documento público, testimonial o dispositivo, que fija una "declaración de ciencia" o una "declaración de voluntad". Este injusto puede cometerse mediante cualquiera de la modalidades designadas en $\operatorname{los}$ numerales $1^{\circ}, 2^{\circ}, 3^{\circ}, 5^{\circ}, 6^{\circ}$ y $7^{\circ}$ del art. 193 precedente. En cambio, el segundo injusto del delito que deriva de la creación de un documento público falso en el sentido de discrepancia entre narración y hecho (art. 193 N. 4 CP), solamente puede realizarse en un documento testimonial público, que fija una "declaración de ciencia". Ambos injustos del delito, por decisión legislativa expresada en el texto del art. $194 \mathrm{CP}$, pueden ser cometidos por el particular. El art. $194 \mathrm{CP}$ describe un delito común.

Por ejemplo, en el caso de introducción (supra 1.), el Notario habría realizado el segundo injusto del delito que deriva de la no correspondencia entre narración y hecho sustancial en el sentido del art. 193 N. 4 CP, al fijar en un documento público la declaración que el sujeto que aparentaba ser el dueño había otorgado la escritura de compraventa del inmueble. Respecto del Notario, en este caso, se trata de un documento testimonial público, que fija una "declaración de ciencia" sobre el hecho de que otro sujeto de nombre A.O.V., dueño del inmueble, había otorgado ante él la escritura de compraventa. En cambio, en el mismo caso de introducción (supra 1.), G.I.V. realizó en coautoría con el otro sujeto el injusto de este delito en el sentido de la creación de un documento público inauténtico, suponiendo la intervención del dueño en el otorgamiento de la escritura de compraventa del inmueble (art. 194 en relación con el art. 193 N. 2 CP). Respecto de G.I.V., este documento público era dispositivo, en la medida en que fijaba las declaraciones de voluntad de las partes compradora y vendedora del inmueble.

El art. 197 CP describe un delito de falsedad cometida en un documento privado o mercantil. La descripción de la conducta prohibida también remite a cualquiera de las modalidades de falsedad designadas en el art. 193 CP. Sin embargo, como se analizó precedentemente (vid. supra 2.3.2.), la verdad del documento privado se reduce a su autenticidad. Por ende, la conducta prohibida por la norma se reduce al injusto del delito que deriva de la creación de un documento privado o mercantil falso en el sentido de inauténtico. Este injusto puede realizarse en cualquier documento privado o mercantil, dispositivo o testimonial, que fija una "declaración de ciencia" o "declaraciones de voluntad". Dado que el injusto se reduce a la creación de un documento privado falso en el sentido de inauténtico, aquél puede cometerse mediante cualquiera de la modalidades designadas en los numerales $1^{\circ}, 2^{\circ}, 3^{\circ}, 5^{\circ}, 6^{\circ}$ y $7^{\circ}$ del art. 193 precedente, con exclusión de la modalidad descrita en el numeral $4^{\circ}$. Este injusto puede ser realizado por cualquier sujeto. El art. $197 \mathrm{CP}$ describe un delito común. 
ROJAS, Luis Emilio. "Deconstrucción del modelo dominante de comprensión de los delitos de falsedad documental".

\section{Cuadro resumen}

\begin{tabular}{|c|c|c|c|}
\hline \multicolumn{2}{|c|}{$\begin{array}{c}\text { Normas de protección a la "verdad" como } \\
\left.\text { autenticidad (art. } 17 \text { inc. } 2^{\circ} \mathrm{CC}\right)\end{array}$} & \multicolumn{2}{|c|}{$\begin{array}{l}\text { Normas de protección a la verdad como } \\
\text { correspondencia (art. } 193 \text { N. } 4 \text { CP) }\end{array}$} \\
\hline Precepto penal & Injusto & Precepto penal & Injusto \\
\hline $\begin{array}{l}\text { Art. } 193 \text { N. } 1 \text { a N. } 3 \text {, } \\
\text { N. } 5 \text { a N. } 8 \text { CP }\end{array}$ & $\begin{array}{l}\text { Creación de un docu- } \\
\text { mento público falso en } \\
\text { el sentido de } \\
\text { inauténtico. }\end{array}$ & Art. 193 N. 4 CP & $\begin{array}{l}\text { Creación de un } \\
\text { documento público } \\
\text { falso en el sentido de no } \\
\text { verdadero. Restringido } \\
\text { a documentos } \\
\text { testimoniales. }\end{array}$ \\
\hline $\begin{array}{l}\text { Art. } 194 \text { remisión al } \\
\text { art. } 193 \text { N. } 1 \text { - N. } 3 \text {, } \\
\text { N. } 5 \text { - N. } 8 \text { CP }\end{array}$ & $\begin{array}{l}\text { Creación de un docu- } \\
\text { mento público falso en } \\
\text { el sentido de } \\
\text { inauténtico. }\end{array}$ & $\begin{array}{l}\text { Art. } 194 \text { remisión al art. } \\
193 \text { N. } 4 \text { CP }\end{array}$ & $\begin{array}{l}\text { Creación de un } \\
\text { documento público } \\
\text { falso en el sentido de no } \\
\text { verdadero. Restringido } \\
\text { a documentos } \\
\text { testimoniales. }\end{array}$ \\
\hline Art. 196 CP: uso & $\begin{array}{l}\text { Realización en lesión } \\
\text { del injusto de peligro } \\
\text { contenido en la } \\
\text { falsedad. }\end{array}$ & Art. 196 CP: uso & $\begin{array}{l}\text { Realización en lesión } \\
\text { del injusto de peligro } \\
\text { contenido en la } \\
\text { falsedad. }\end{array}$ \\
\hline Art. $197 \mathrm{CP}$ & $\begin{array}{l}\text { Creación de un docu- } \\
\text { mento privado falso en } \\
\text { el sentido de } \\
\text { inauténtico. }\end{array}$ & & \\
\hline Art. 198 CP: uso & $\begin{array}{l}\text { Realización en lesión } \\
\text { del injusto de peligro } \\
\text { contenido en la } \\
\text { falsedad. }\end{array}$ & & \\
\hline
\end{tabular}


Polít. crim. Vol. 9, № 18 (Diciembre 2014), Art. 6, pp. 477-520.

[http://www.politicacriminal.cl/Vol_09/n_18/Vol9N18A6.pdf]

\section{Conclusiones}

5.1. La doctrina y jurisprudencia suelen leer el texto de los artículos 193, 194 y 197 CP desde la óptica de un modelo determinado de comprensión. Este modelo de comprensión se encuentra inmerso en una serie de dicotomías, que le impide a la doctrina y jurisprudencia ver el injusto propio de los delitos descritos en dichos artículos del Código penal. Estas dicotomías son cuatro: $1^{\mathrm{a}}$, fe pública como bien jurídico colectivo / patrimonio como bien jurídico personal; $2^{\mathrm{a}}$, documento público como portador de fe pública / documento privado como mero instrumento de la defraudación patrimonial; $3^{\mathrm{a}}$, falsedad ideológica / falsedad material como injustos esencialmente diferentes, y $4^{\mathrm{a}}$, delito especial / delito común con la forma intermedia de un delito "híbrido".

5.2. Este modelo de comprensión, preso de estas dicotomías latamente analizadas, gatilla en la doctrina y jurisprudencia una manera francamente enrevesada de leer el texto de los artículos 193, 194 y 197 CP. Según esta lectura, el art. 193 no establece un delito de falsedad en documento público, sino que, en el fondo, un delito funcionario. El art. $194 \mathrm{CP}$ tampoco establecería simplemente un delito de falsedad en documento público, sino que una forma delictiva híbrida, que pende entre la falsificación material de un documento público y la falsedad ideológica, cuya punibilidad queda supeditada a la búsqueda de otra norma penal relativa a tal clase de falsedad o, en su defecto, de otra norma penal que tienda a la protección de otros intereses, como por ejemplo el patrimonio (v.gr.: art. 468, 471 N. 2, $473 \mathrm{CP}$, etc.). El art. $197 \mathrm{CP}$ tampoco establecería un delito de falsedad documental, sino que un delito patrimonial.

5.3. Este modelo de comprensión se encuentra tan asentado en la doctrina y jurisprudencia, que opera casi por inercia. ¿Qué motivos y razones llevan a que doctrina y jurisprudencia lo acepten inconsciente o conscientemente? Los motivos inconscientes parecen remontarse a una técnica de legislación penal decimonónica y, por ende, antigua. Esta legislación penal antepone, por una parte, el concepto de fe pública y, por otra, alude en el art. 197 al "perjuicio de tercero", lo cual gatilla la $1^{a}$ dicotomía analizada (supra 2.1.). Las razones conscientes parecen provenir del esfuerzo por delimitar y acotar el ámbito de aplicación de las normas de los artículos 193, 194 y 197 CP. Pero el costo analítico de este esfuerzo es demasiado alto, pues conduce a una lectura de estos artículos, según la cual estas disposiciones establecen delitos básicamente diferentes de los contemplados en el texto de la ley: $1^{\circ}$, un delito funcionario, $2^{\circ}$, un delito híbrido y $3^{\circ}$, un delito patrimonial. Esta lectura puede considerarse más o menos razonable, incluso puede tratarse de fundamentarla en la teoría del bien jurídico. Este intento podría resultar en relación con la norma del art. 193 o la del art. 197 CP, pero respecto de una figura híbrida como sería la del art. $194 \mathrm{CP}$, ¿qué justificación racional podría proponerse respecto de su fundamento? ¿cuál podría ser el fundamento racional de una norma de tal naturaleza? Un tal intento de justificación racional parece ser una empresa imposible de realizar.

5.4. ¿Cómo pudo ser el legislador penal del siglo XIX tan asistemático de anteponer en el art. 193 un delito funcionario y de adelantar en más de doscientos (200) artículos en el art. 197 un delito patrimonial? Tales intenciones parecen situarse más allá del espíritu de la legislación penal. En todo caso, esta lectura se sitúa claramente al margen del texto expreso de los artículos 193, 194 y 197 CP. Sentido y fin del análisis precedente radica simplemente 
ROJAS, Luis Emilio. "Deconstrucción del modelo dominante de comprensión de los delitos de falsedad documental".

en restituir su dignidad a cada una de estas normas del Código penal. La tesis que se sostiene consiste sencillamente en que estos artículos del Código penal establecen aquello que su texto expresamente describe: delitos de falsedad documental. 
Polít. crim. Vol. 9, № 18 (Diciembre 2014), Art. 6, pp. 477-520.

[http://www.politicacriminal.cl/Vol_09/n_18/Vol9N18A6.pdf]

\section{BIBLIOGRAFÍA}

Actas de las sesiones de la Comisión Redactora del Código penal chileno, Santiago: Imprenta de la República de Jacinto Nuñez, 1873, edición facsímil, Santiago, 2013.

BACIGALUPO, Enrique, Falsedad documental, estafa y administración desleal, Madrid/Barcelona/Buenos Aires: Marcial Pons, 2007.

BINDING, Karl, Lehrbuch des gemeinen deutschen Strafrechts, Besonderer Teil, t. II, Leipzig: Engelmann, 1904.

BOLDOVA PASAMAR, Miguel Ángel, Estudio del bien jurídico protegido en las falsedades documentales, Granada, 2000.

CARRARA, Francesco, Programa de Derecho criminal, PE vol. VII, $5^{\text {a }}$ ed., Santa Fe de Bogotá: Temis, 1996.

COUSIÑO MAC IVER, Luis, "La falsificación de instrumento privado", Revista de Ciencias Penales, $2^{\mathrm{a}}$ época, t. VII (1944), pp. 5-23, pp. 99-206.

COUTURE, Eduardo, Estudios de Derecho procesal civil, t. II, $3^{\mathrm{a}}$ ed., Buenos Aires: De Palma, 1998.

D’ORS, Álvaro, “Contribución al historia del 'crimen falsi”, en: VOLTERRA, Edoardo, Studi in onore die Edoardo Volterra, vol. II, Milano: Giuffrè, 1969, pp. 527-558.

ECHANO BASALDÚA, Juan, “¿Falsedad ideológica de particular en escritura pública? (revisión de la doctrina jurisprudencial)", en: VV. AA., Estudios penales en memoria del profesor Agustín Fernández-Albor, Santiago de Compostela: Universidad Santiago de Compostela, 1989, pp. 253-269.

ETCHEBERRY, Alfredo, "El objeto jurídico en los delitos de falsedad documental", Revista de Ciencias Penales, $3^{\mathrm{a}}$ época, N. 2, t. XX (1961), pp. 33-66.

, "El objeto material del delito de falsedad documental", Revista de Ciencias Penales, 3a época, N. 2 t. XX (1961), pp. 219-240.

Alfredo, Derecho penal, parte especial, t. IV, $3^{\mathrm{a}}$ ed., Santiago: Editorial Jurídica de Chile, 1997.

FERNÁNDEZ PANTOJA, Pilar, Delito de falsedad en documento público, oficial y mercantil, Madrid: Marcial Pons, 1996.

FILANGIERI, Gaetano, Ciencia de la legislación, Madrid: Imprenta que fue de Fuentenebro, 1813.

GARCÍA CANTIZANO, María del Carmen, Falsedades documentales (en el Código penal de 1995), Valencia: Tirant lo Blanch, 1997.

GRISOLÍA, Francisco, "Nota", Revista de Ciencias Penales, 3a época, N. 2 mayo / diciembre t. XV (1956), pp. 95-98.

GARRAUD, René, Droit Pénal Français, t. III, $2^{\mathrm{a}}$ ed., Paris: Larose, 1899.

GARRIDO MONTT, Mario, Derecho penal, parte especial, t. IV, $4^{\text {a }}$ ed., Santiago: Editorial Jurídica de Chile, 2008.

GUZMÁN DALBORA, José Luis, Estudios y defensas penales, $3^{\mathrm{a}}$ ed., Santiago: Legal Publishing, 2009.

HERNANDEZ, Héctor; COUSO, Jaime (dirs.), Código penal comentado, Santiago: Ed. AbeledoPerrot/Legal publishing, 2011.

JAKOBS, Günther, Strafrecht, Allgemeiner Teil, $2^{\mathrm{a}}$ ed., Berlin/New York: De Gruyter, 1993.

KIENAPFEL, Diethelm, Urkunden im Strafrecht, Frankfurt: Klostermann, a.M., 1967. 
ROJAS, Luis Emilio. “Deconstrucción del modelo dominante de comprensión de los delitos de falsedad documental".

, „Urkundenbegriff und ,Rechtserheblichkeit“", Zeitschrift für die gesamte Strafrechtswissenschaft, vol. 82 (1970), pp. 344-378.

MARTÍNEZ-PEREDA, José Manuel, "Las falsedades en documentos oficiales”, en: VV. AA., Las falsedades documentales, Libro homenaje a Enrique Ruiz Vadillo, Granada: Comares, 1994, pp. 77-120.

ORTIZ, Pedro, "La falsificación de instrumento privado", Revista de Ciencias Penales, $2^{\mathrm{a}}$ época, t. VII (1944), pp. 207-213.

POLITOFF, Sergio; MATUS, Jean Pierre; RAMÍREZ, Cecilia, Lecciones de Derecho Penal Chileno, parte especial, reimpresión de la $2^{\mathrm{a}}$ edición, Santiago: Editorial Jurídica de Chile, 2009.

PUPPE, Ingeborg, „Nomos Kommentar“, en: KINDHÄUSER, Urs, NEUMANN, Ulfrid; PAEFFGEN, Hans-Ulrrich (Eds.), $\S ~ 267,271,348$ StGB, 4a ed., Baden-Baden: Nomos Verlag, 2013.

PUPPE, Ingeborg, „Die Wahrheitspflicht des Notars“, en: KINDHÄUSER, Urs (ed.), Strafrechtliche Aspekte notarieller Tätigkeit, Baden-Baden: Nomos, 2009, pp. 8-16.

QUINTANO RIPOLLÉS, Antonio, La falsedad documental, Madrid: Reus, 1952.

RIVACOBA Y RIVACOBA, Manuel, "Objeto jurídico y sujeto pasivo de la falsificación de monedas", Gaceta Jurídica N. 70, abril (1986), pp. 2-9.

RODRÍGUEZ COLLAO, Luis; VERA, Jaime, "El bien jurídico protegido en los delitos de falsedad", Revista de Derecho, UC Temuco, año 5, núm. 5 (2004), pp. 109-137.

ROJAS AGUIRRE, Luis Emilio, "Historia dogmática de la falsedad documental", Revista de Derecho, Pontificia Universidad Católica de Valparaíso, vol. 39, $2^{\circ}$ semestre (2012), pp. 545-583.

, "Falsedad documental como delito de engaño", Revista Chilena de Derecho, Pontificia Universidad Católica de Chile (2014, en prensa).

ROXIN, Claus, Täterschaft und Tatherrschaft, $8^{\mathrm{a}}$ ed., Berlin: De Gruyter, 2006.

SEARLE, John R., La construcción de la realidad social, Barcelona/Buenos Aires/México: Paidós, 1997.

VARGAS, Tatiana, Falsificación de instrumento privado. Un estudio práctico entre la falsificación y la estafa, Santiago: Legal Publishing/Thomson Reuters, 2013.

VILLACAMPA ESTIARTE, Carolina, La falsedad documental: análisis jurídico penal, Barcelona: Cedecs, 1999. 